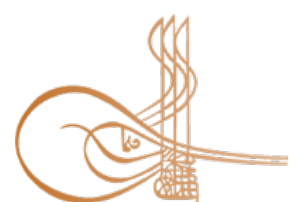

www.turkishstudies.net/economy
Turkish Studies - Economics, Finance, Politics

eISSN: $2667-5625$

Research Article / Araştırma Makalesi

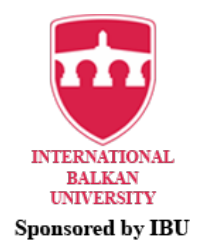

Sponsored by IBU

\title{
Vergi Çekiciliğinin Doğrudan Yabancı Yatırım Girişlerine Etkisi: Gelişmiş ve Gelişmekte Olan Ülkeler İçin Panel Veri Analizi
}

\author{
The Effect of Tax Attractiveness on Direct Foreign Investment Inflows: Panel Data Analysis for \\ Developed and Developing Countries
}

\author{
Hüseyin Kutbay*
}

\begin{abstract}
In the study, the effect of tax attractiveness, which includes many incentive items, on Foreign Direct Investment (FDI) inflows, was analyzed by panel data analysis for developed and developing country groups using 2007-2018 period data. Since the tax attractiveness index has been published annually since 2007, this year has been preferred as the starting year. In addition, trade openness, economic freedom index and increase in per capita national income data, which may have an impact on FDI inflows, are also included in the model. Since the model established for developed and developing countries has a horizontal cross-section dependency, the existence of the unit root in the variables was made with Pesaran (2007). Afterwards, it was decided to apply the fixed effect model in developed countries and the random effect model in developing countries with Hausman test. Since the variance, autocorrelation and horizontal cross-section dependency were found in the models, the analysis was estimated by Driscoll Kraay test. As a result of the study, the effect of tax attractiveness on FDI inflows in both country groups was found to be positive and statistically significant. Policy makers can use this information for future tax reforms that can be targeted to increase the attractiveness of the location. While the effect of increase in per capita income per capita on the FDI inflows in developed countries was positive but statistically insignificant, the effect of other variables was found positive and significant for both country groups.
\end{abstract}

Structured Abstract: The increase in the mobility of capital along with globalization and the increase in the understanding of the importance of FDI for the economies of nations have forced countries to compete in the incentives offered for these investments. Because FDI inflows are an important determinant of the economic growth of countries, an important measure of investment attractiveness and an indicator of the internationalization of the country, every country desires to make these investments in their own countries. Tax attractiveness shows the appeal of a country's tax environment and tax planning opportunities for companies. The tax attractiveness, which reflects the tax planning opportunities that the capital owner in a country should consider when making his decisions about where to invest, was first created by Simmonss under the name of "corporate tax attractiveness index". Since the corporate tax attractiveness index is made to a certain number of executives for only 1 year and includes only country factors such as corporate tax etc. in directing FDI into

\footnotetext{
* Dr. Öğr. Üyesi, Karamanoğlu Mehmetbey Üniversitesi, Uygulamalı Bilimler Yüksekokulu, Uluslararası Ticaret ve Lojistik Yönetimi Bölümü

Asst. Prof. Dr, Karamanoglu Mehmetbey University, School of Applied Sciences, Department of International Trade and Logistics Management ORCID 0000-0002-8819-1846

hkutbay@kmu.edu.tr

Cite as/ Atıf: Kutbay, H. (2020). Vergi çekiciliğinin doğrudan yabancı yatırım girişlerine etkisi: gelişmiş ve gelişmekte olan ülkeler için panel veri analizi. Turkish Studies - Economy, 15(2), 855-873. https://dx.doi.org/10.29228/TurkishStudies.42025

Received/Geliş: 05 April/Nisan 2020

Accepted/Kabul: 20 June/Haziran 2020

Copyright $($ INTAC LTD, Turkey

Checked by plagiarism software

Published/Yaym: 25 June/Haziran 2020

CC BY-NC 4.0
} 
a country, this index was found insufficient by German economists Keller and Schanz. Therefore, in 2005, they developed the tax attractiveness index, which is an annual index developed for 100 countries, using 16 different variables that can directly affect foreign capital flows.

In this study, the effect of tax attractiveness index on FDI inflows was investigated for developed (41) and developing (42) countries within the 2007-2018 period. In addition, it has been determined in which country category that tax attractiveness has an effect on foreign capital inflows. Although there are many domestic and foreign studies examining the effect of tax incentives on FDI inflows, there are not many studies on tax attractiveness. The studies on tax attractiveness and foreign direct investment inflows are given below. Tung and Cho (2000) examined whether the creation of special tax incentive zones had an impact on FDI inflows for 5 specific regions in China. Simmons (2003) examined whether a country's corporate tax regime had a significant impact on FDI inflows within the scope of 7 countries (Singapore, People's Republic of China, Hong Kong, Australia, Canada, the UK and the USA) for 1999. Cristina (2012), whether tax attractiveness (includes corporate tax rate representing direct taxation, value added tax representing indirect taxation and social security contributions and ease of payment), whether it affects the attractiveness of Central and Eastern European countries for foreign investors, 2007-2010 analyzed in scope. Dinkel, Keller and Schanz (2014) investigated whether the tax environment measured by the host country's tax attractiveness index played an important role in determining the number of German-controlled subsidiaries located in that country and found that a country's tax attractiveness had a positive effect on the number of affiliates. Dinkel (2015) investigated whether countries' tax attractiveness has an impact on the geographical risk distribution of multinational companies.

In the model created to analyze the effect of tax attractiveness on foreign direct investment inflows, the presence of variance variance, autocorrelation and horizontal cross-section dependence was determined. Therefore, the Driscoll Kraay model, which can predict by taking these problems into account, was preferred. According to the results of Driscoll Kraay standard error model estimation, which was made considering the presence of variance, autocorrelation and horizontal cross-section dependency, the effect of tax attractiveness index, trade openness and economic freedom index, which are independent variables in developed countries, was positive and significant, while GDP per capita in per capita the rate of change was positive but meaningless. In the developing country group, the effect of all variables on FDI inflows was found positive and significant. This situation shows that in the developed and developing country groups, the tax attracting environment has a very beneficial effect on firms investing in foreign countries. In addition, it was concluded that the 1-unit increase in tax attractiveness in the estimation results increased FDI inflows in developing countries (2.72) more than developed countries (2.11). The estimation results obtained show that the developing countries lack the FDI inflow compared to the developed countries and shows that every improvement in tax attractiveness will increase FDI inflows.

In the study, tax attractiveness index, which is an important indicator among many factors in investment location decisions, and trade openness, economic freedom index and increase in per capita national income are taken into account as a control variable. In future studies, factors such as political stability, size of the local market, and proximity to markets can be analyzed, which may affect FDI inflows. In addition, since each incentive item has different dimensions, it can be estimated that each of the tax attractiveness items should be examined separately and accordingly, which items should or should not be provided for FDI entries.

Keywords: Tax Attractiveness, FDI, Developed Countries, Developing Countries, Panel Data Analysis

Öz: Çalışmada birçok teşvik kalemini içeren vergi çekiciliğinin Doğrudan Yabancı Yatırım (DYY) girişleri üzerindeki etkisi 2007-2018 dönem verileri kullanılarak gelişmiş ve gelişmekte olan ülke grupları için panel veri analizi ile incelenmiştir. Vergi çekiciliği endeksi 2007 yılından itibaren yıllık olarak yayınlandığı için başlangıç yılı olarak bu yıl tercih edilmiştir. Ayrıca DYY girişleri üzerinde etkisi olabilecek ticari açıklık, ekonomik özgürlük endeksi ve kişi başına düşen milli gelirdeki artış verileri de modele dâhil edilmiştir. Gelişmiş ve gelişmekte olan ülkeler için kurulan modelde yatay kesit bağımlllığı bulunduğu için değişkenlerdeki birim kökün varlığı Pesaran (2007) ile yapılmıştır. Daha sonrasında Hausman testi ile gelişmiş ülkelerde sabit etkili modelin, gelişmekte olan ülkelerde ise rassal etkili modelin uygulanmasına karar verilmiştir. Modellerde değişen varyans, otokorelasyon ve yatay kesit bağımlılığı olduğu tespit edildiği için analiz Driscoll Kraay testi ile tahmin edilmiştir. Çalışmanın neticesinde vergi çekiciliğinin her iki ülke 
grubunda da DYY girişleri üzerindeki etkisi pozitif ve istatistiki olarak anlamlı bulunmuştur. Politika yapıcılar bu bilgiyi, konumun çekiciliğini artırmak için hedeflenebilecek gelecekteki vergi reformları için kullanabilirler. Kontrol değişkenlerden kişi başına düşen milli gelirdeki artışın geliş̧iş ülkelerde DYY girişleri üzerindeki etkisi pozitif ancak istatistiki olarak anlamsız bulunmuşken diğer değişkenlerin etkisi her iki ülke grubu için pozitif ve anlamlı bulunmuştur.

Anahtar Kelimeler: Vergi Çekiciliği, DYY, Gelişmiş Ülkeler, Gelişmekte Olan Ülkeler, Panel Veri Analizi

\section{Giriş}

Küreselleşme ile birlikte sermayenin hareketliliğindeki artış ve bunu takiben de ulusların ekonomileri için DYY'lerin önemini kavramasındaki artış, bu yatırımlar için sunulan teşviklerde ülkeleri rekabet etme yarışına zorlamıştır. Çünkü DYY girişleri ülkelerin ekonomik büyümesinin önemli bir belirleyicisi, yatırım çekiciliğinin önemli bir ölçüsü ve ülkenin uluslararasılaşmasının bir göstergesi olduğundan her ülke bu yatırımların kendi ülkelerinde gerçekleştirilmesini arzulamaktadır. Bu arzularını gerçekleştirmek için de yabancı sermeye girişlerine yönelik farklı türde ve oranda cezbedici teşvikler uygulamaktadırlar. Bu teşviklerden birini de vergisel imtiyazlar oluşturmaktadır. Vergi teşvikleri tüm dünyada, özellikle gelişmekte olan ülkelerde yabancı sermaye yatırımlarını çekmede önemli bir politika aracı olarak kullanılmaktadır. Hükümetler, bazı ekonomik faaliyetlere daha uygun vergi muamelesi sağlayan vergi teşvikleri kullanarak yerli ve yabancı sermayeyi yeniden tahsis etmeye veya çekmeye çalışmaktadırlar. Bu uygulamanın yaygın örnekleri, kurumlar vergisi oranlarının düşürülmesi, kurumlar vergisi üzerindeki geçici muafiyetler (vergi tatilleri), vergi kredisi veya yatırım indirimleri yoluyla vergi yükünün azaltılması, cari dönem zararların ileriye veya geriye yönelik olarak indirime tabi tutulması vb. şeklinde tezahür etmektedir. Yabancı sermaye girişleri için sağlanan teşviklerde temel mantık, yatırım yapan firmaların faydalarının maliyetleri aştığı sürece yatırımlarına devam edecekleri veya yatırımlarını daha da artıracakları düşüncesine dayanmaktadır. Bu teoriye göre ülkelerin sundukları teşvikler, diğer ülkelerin sağladıkları teşvikler ile karşılaştırıldığında, yatırım maliyetlerini ne kadar fazla azaltıyorsa yatırımcıların o ülkeye yatırım yapması daha olasıdır. Vergi teşviklerinin yabancı sermaye girişleri üzerindeki etkisini analiz eden mevcut çalışmaların çoğunda vergilendirmenin şirket kararları üzerindeki etkisini açıklamak için ya yasal vergi oranını ya da efektif vergi oranı uygulanmaktadır. Ancak yasal vergi oranının, vergi tabanı etkilerini ihmal ettiği için doğrudan sermaye girişleri için tatmin edici olmayan bir vekil olduğunu belirten çalışmalarda olup bu çalışmalarda eksikliğin kısmen üstesinden gelmek için amortisman ve faiz giderlerinin indirimini de dikkate alan ve vergi matrahını düşüren vergi teşvikleri de hesaba katılmıştır. Ancak bu önlemler, yatırımların yeri ve hacmi için önemli olan çok az vergi kuralını içerdiği için Keller ve Schanz (2013) tarafından eleştirilmiştir. Keller ve Schanz sermaye akışlarını sadece birkaç teşvik aracının etkilemeyeceğini, yerel ve sınır ötesi diğer vergi kurallarının da çok uluslu işletmelerin yer kararlarını etkileyebileceğini ifade etmişler ve sermaye akışlarına yön verebilecek 20 teşvik bileşenini içeren bir vergi çekiciliği endeksi oluşturmuşlardır.

Bu çalışmada vergi çekiciliği endeksinin DYY girişleri üzerindeki etkisi 2007-2018 dönemi kapsamında gelişmiş (41) ve gelişmekte olan (42) ülkeler için araştırılmış ve vergi çekiciliğinin hangi ülke kategorisinde yabancı sermaye girişleri üzerinde etkisinin olup olmadığı tespit edilmiştir. Vergi teşviklerinin DYY girişleri üzerindeki etkisini inceleyen yerli ve yabancı birçok çalışma olmasına rağmen, vergi çekiciliğini konu edinen çok fazla çalışma bulunmamaktadır. Vergi çekiciliğinin yatırım kararları üzerindeki etkisi sadece bu endeksi bulan ve geliştirenler tarafindan araştırılmış olup bu konuyla ilgili olarak yerli bir kaynak bulunmamaktadır. Bu yönüyle çalışmanın literatüre katkı sağlayacağı düşünülmektedir. 


\section{Vergi Çekiciliği}

Vergi çekiciliği, bir ülkenin vergi ortamının albenisini ve şirketler için vergi planlaması olanaklarını göstermektedir. Bir ülkedeki sermaye sahibinin yatırımlarını nerede gerçekleştireceğine ilişkin kararlarını alırken göz önünde bulundurması gereken vergi planlama fırsatlarını yansıtan vergi çekiciliği, ilk olarak Simmonss tarafından "kurumlar vergisi çekicilik endeksi" adı altında oluşturulmuştur. Endeks, çok uluslu şirketlerden (500), bankacılık ve finans endüstrisinden (100) ve biri ABD'den, diğeri de Hong Kong'da bulunan şirket yöneticilerinden seçilen toplam da 602 şirket yöneticisinin geçmiş 5 yıldaki tecrübelerine göre yapılan bir anket çalışması ile sadece 1 yıl için (1999) hesaplanmıştır. Ancak anket sorularının gönderildiği 24 ülke de bulunan 602 yöneticinin sadece 16 ülkede bulunan 92 yöneticisi geri dönüş yapmış ve endeks bu veriler üzerinden oluşturulmuştur. Anket 22 sorudan oluşmakta olup 1 (hiç önemli değil) ila 10 (son derece önemli) arasında bir ölçekte, doğrudan yatırımın yeri ile ilgili karar verme sürecinde potansiyel olarak yer alan faktörlerin değerlendirmesini kapsamaktadır (Simmons, 2000:11-12). Kurumlar vergisi çekicilik endeksi sadece 1 yıl için belirli sayıdaki yöneticilere yapıldığından ve DYY'lerin bir ülkeye yönlendirilmesinde sadece kurumlar vergisi vb. ülkeye özgü faktörleri kapsadığından Alman iktisatçılar Keller ve Schanz tarafından bu endeks yetersiz görülmüştür. Bu yüzden 2005 yılında doğrudan yabancı sermaye akımlarını etkileyebilecek 16 farklı değişken kullanılarak 100 ülke için geliştirilmiş yıllık bir endeks olan vergi çekiciliği endeksini geliştirmişlerdir. Bu endeks, stopaj vergileri, temettü ve sermaye kazançlarının vergilendirilmesi, grup vergilendirme rejimleri ve çifte vergi antlaşmaları gibi sınır ötesi vergi parametrelerini de içermekte olduğundan, firmaların ve bireylerin belirli ülkelerde yapacakları yatırım kararlarında yararlanabileceği vergi planlama firsatlarını gösteren önemli bir göstergeyi temsil etmektedir (Keller ve Schanz, 2013: 2). Firmaların yatırım kararlarını alırken kurumsal konumlar ile ilgili dünya ülkelerindeki vergi sistemlerinin avantajlarını gösteren vergi çekiciliği endeksi, Dinkel tarafından Keller ve Schanz'in kullandığı 16 bileşene dört bileşen daha eklenerek daha da geliştirilmiştir. Bir ülkenin vergi ortamını belirleyen ve bir dizi vergi parametresinin ağırlıklı ortalaması alınarak oluşturulan endeks, sıfır ile bir arasında değişen değerlerden oluşmaktadır. Endeks değerleri bire yaklaştıkça, kurumsal bir perspektiften belirli bir ülkenin vergi ortamının DYY açısından daha cazip olduğunu göstermektedir (Tahlova ve Banociova, 2019: 92). Vergi çekicilik endeksi, yatırım akışlarına yön vermede yasal vergi oranına nazaran daha iyi bir göstergedir. Çünkü yüksek vergi oranı uygulayan ülkeler, yabancı yatırımlar için uygun vergi koşulları da sunabilmektedirler. Bu nedenle ülkeler firmaları ve yatırımları kendi ülkelerine çekmek için başka teşvikler belirleyebileceğinden, yasal vergi oranı her durumda ülkenin vergi iklimi için uygun bir vekil değildir. Vergi çekicilik endeksi ise yalnızca az sayıda gerçek dünya vergi bileşenini ele alan mevcut vergi önlemlerinin aksine, özellikle bir ülkenin sunduğu vergi planlama firsatlarını yansıtan 20 farklı vergi faktörünü kapsadığından, DYY'lerin nereye yapılması gerektiğine karar verilmesinde önemli bir göstergeyi teşkil etmektedir (Dinkel, Keller ve Schanz, 2014: 3). Vergi çekicilik endeksinin hesaplanmasında kullanılan bileşenlerin çoğu mevcut vergi önlemlerinde ihmal edilmiş olduğundan, vergi çekicilik endeksi, bir ülkenin vergi ortamının çekiciliğini ve sunulan vergi planlama firsatlarını ölçmek için yeni bir yaklaşımı temsil etmekte olup Tablo 1'de belirtilen bileşenler dikkate alınarak hesaplanmaktadır.

Tablo 1: Vergi Çekicilik Endeksi Bileşenleri, Ölçümü ve Ağırlıkları

\begin{tabular}{|c|l|c|}
\hline $\begin{array}{c}\text { Endeks } \\
\text { ileşenleri }\end{array}$ & \multicolumn{1}{|c|}{ Ölçüm $(0-1$ arasında bir değer kullanılmaktadır $)$} & A ğırlık \\
\hline $\begin{array}{c}\text { Kaçınma Önleme } \\
\text { Kuralları }\end{array}$ & $\begin{array}{l}\text { Ulusal vergi kanununun vergiden kaçınmayı önleme kurallları içermemesi } \\
\text { durumunda 1, Ulusal vergi kanununun vergiden kaçınmayı önleme kuralları } \\
\text { içermesi durumunda 0.5, Ulusal vergi kanununun vergiden kaçınma ile ilgili } \\
\text { genel ve özel bir kaçınma önleme kuralları içermesi durumunda ise 0 }\end{array}$ & $1 / 20$ \\
\hline $\begin{array}{c}\text { Kontrollü } \\
\text { Yabancı Şirket } \\
\text { Kuralı }\end{array}$ & $\begin{array}{l}\text { Kontrollü yabancı şirket kuralı uygulanmıyorsa 1 } \\
\text { Kontrollü yabancı şirket kuralı uygulanıyorsa, 0 }\end{array}$ & $1 / 20$ \\
\hline
\end{tabular}

Turkish Studies - Economy, 15(2) 


\begin{tabular}{|c|c|c|}
\hline KVO & $\begin{array}{l}\text { (Maksimum kurumlar vergisi oranıt - vergi oran } 1_{i t} \text { ) / maksimum vergi oranı } \\
\text { Değerin yüksek olması, düșük oranda vergi uygulandığını belirtmektedir }\end{array}$ & $1 / 20$ \\
\hline Amortismanlar & $\begin{array}{l}\text { Vergi öncesi amortisman karşılıklarının bugünkü değeri / maksimum } \\
\text { amortisman (ülkelerarasında gözlemlenen en yüksek değerdir) }\end{array}$ & $1 / 20$ \\
\hline AB Üye Devleti & Avrupa Birliği üye devleti ise 1 , Avrupa Birliği üye devleti değilse 0 & $1 / 20$ \\
\hline \multirow{3}{*}{$\begin{array}{l}\text { Grup } \\
\text { Vergilendirme } \\
\text { Rejimi }\end{array}$} & $\begin{array}{l}\text { Uluslararası grup vergilendirme rejimine (aynı şirket grubuna ait birden fazla } \\
\text { ortaklığın konsolide vergi beyannamesi vermesi) izin veren ülkeler, } 1\end{array}$ & \multirow{3}{*}{$1 / 20$} \\
\hline & Grup vergilendirme rejimini yerel grup üyeleriyle sinırlandıran ülkeler, 0.5 & \\
\hline & Grup vergilendirme rejimine izin vermeyen ülkeler, 0 & \\
\hline Vergi Ortamı & $\begin{array}{l}\text { Kurumlar vergisi planlama stratejisinde merkezi bir araç işlevi görmektedir. } \\
\text { Cari vergilendirmeden veya yerel kurumlar vergisinden muafiyeti içermekte } \\
\text { olup özel bir vergi ortamı sunan ülkeler } 1 \text {, sunmayan ülkeler } 0 \text { değeri alır }\end{array}$ & $1 / 20$ \\
\hline $\begin{array}{l}\text { Geriye Dönük } \\
\text { Zarar Mahsubu }\end{array}$ & $\begin{array}{l}\text { Cari dönem zararların, geçmiş dönem karlarına mahsup edilmesine izin veren } \\
\text { ülkeler } 1, \text { mahsup edilmesine izin vermeyen ülkeler } 0\end{array}$ & $1 / 20$ \\
\hline $\begin{array}{l}\text { İleriye Dönük } \\
\text { Zarar Mahsubu }\end{array}$ & $\begin{array}{l}\text { Cari dönem zararların gelecek dönem karlarına mahsup edilmesidir. } \\
\text { Mahsub edilecek yıl } \geq 20 \text { ise } 1,>5 \text { ve } \leq 20 \text { ise } 0.5, \leq 5 \text { ise } 0 \text { değer alır. }\end{array}$ & $1 / 20$ \\
\hline $\begin{array}{l}\text { Patent Kutusu } \\
\text { Rejimi }\end{array}$ & $\begin{array}{l}\text { Telif hakları için düşük oranlı vergilerin veya muafiyetin uygulandığı bir } \\
\text { teşvik türüdür. [( } 1 \text { - gayrimaddi hak bedelleri için vergiden muaf gelir) } \times \\
\text { işletme gelirlerine ilişkin yasal vergi oranı] efektif vergi oranını ifade } \\
\text { etmektedir. } \mathrm{Bu} \text { oran daha sonra sıfır ile bir arasında olacak şekilde } \\
\text { ölçeklendirilir [(yıllık gayrimaddi hak bedellerine uygulanan maksimum } \\
\text { vergi oranı - yılllk gayrimaddi hak bedellerine uygulanan vergi oranı)/ yıllık } \\
\text { gayrimaddi hak bedellerine uygulanan maksimum vergi oranı]. }\end{array}$ & $1 / 20$ \\
\hline $\begin{array}{l}\text { Kişisel Gelir } \\
\text { Vergisi Oranı }\end{array}$ & $\begin{array}{l}\left.\text { [(maksimum kişisel gelir vergisi oranıt }- \text { vergi oran1 }{ }_{1 \mathrm{t}}\right) \text { / maksimum vergi } \\
\text { oranı] sıfır ile bir arasında ölçeklendirilir. Daha yükssek bir değer, daha cazip } \\
\text { kişisel gelir vergisi oranını (yani daha düşük) gösterir. }\end{array}$ & $1 / 20$ \\
\hline $\begin{array}{l}\text { Ar-Ge Vergi } \\
\text { Teşvikleri }\end{array}$ & $\begin{array}{l}\text { Ar-Ge vergi kredileri veya vergi indirimleri Ar-Ge maliyetinin yüzdesi } \\
\text { olarak ilgili yllın dünyadaki en çekici } \% 25 \text { 'i arasında yer alıyorsa } 1 \text {, } \\
\text { Ar-Ge vergi kresdisi veya vergi indirimi uyguluyor ancak } \% 25 \text { içerisinde yer } \\
\text { almıyorsa } 0.5 \text {, Ar-Ge teşviki uygulamıyorsa } 0 \text { değeri alır. }\end{array}$ & $1 / 20$ \\
\hline $\begin{array}{l}\text { Sermaye } \\
\text { Kazançlarının } \\
\text { Vergilendirilmesi }\end{array}$ & $\begin{array}{l}\text { Sermaye kazançlarının vergilendirilmesi çifte vergilendirmeye neden } \\
\text { olduğundan birçok ülke sermaye kazançları için (kımi) vergi muafiyeti } \\
\text { uygulamaktadır. Sermaye kazançlarının vergilendirilmesinde uygulanan } \\
\text { vergi muafiyetinin yüzdesi ile ölçülmektedir (ondalık sayı olarak) }\end{array}$ & $1 / 20$ \\
\hline $\begin{array}{l}\text { Temettülerin } \\
\text { Vergilendirilmesi }\end{array}$ & $\begin{array}{l}\text { Temettülerin vergilendirilmesinde uygulanan vergi muafiyetinin yüzdesi ile } \\
\text { ölçülmektedir. Örneğin temettülerin vergiye tabi olmadığı ülkeler }(\% 100 \\
\text { muafiyet) } 1 \text {, tamamen vergiye tabi olduğu ülkeler } 0 \text { değer alır }\end{array}$ & $1 / 20$ \\
\hline Faiz Kuralları & $\begin{array}{l}\text { Faiz giderlerinin vergiye tabi gelirden düşülebilirliğinin sınırlandırılmasını } \\
\text { ifade etmektedir. Herhangi bir sınırlandırma uygulamayan ülkeler } 1 \text {, } \\
\text { sınırlandırma hakkı olan ülkeler } 0.5 \text { ve sınırlandırma uygulayan ülkeler ise } 0\end{array}$ & $1 / 20$ \\
\hline $\begin{array}{l}\text { Transfer } \\
\text { Fiyatlandırması }\end{array}$ & $\begin{array}{l}\text { Ülkede transfer fiyatlandırması ile ilgili özel bir kural yoksa } 1 \text {, Transfer } \\
\text { fiyatlandırması ile ilgili özel bir kural varsa } 0 \text { değeri alır }\end{array}$ & $1 / 20$ \\
\hline Antlaşma Ăg1 & $\begin{array}{l}\text { Çifte vergi anlaşmaları, yabancı kaynaklı gelirlerden elde edilen kârın çifte } \\
\text { vergilendirilmesinden kaçınmaya yardımcı olur. Ayrıca, dağıtılan karlar ile } \\
\text { faiz ve telif ödemeleri üzerinden alınan stopaj vergilerini azaltma veya hatta } \\
\text { bunlardan kaçınma amacına da hizmet etmektedir. Antlaşma Ağı, bir } \\
\text { ülkedeki çifte vergi antlaşması sayısının bir yıl içinde tüm ülkeler arasında } \\
\text { gözlemlenen maksimum sayıya bölünmesiyle sıfır ile bir arasında değişecek } \\
\text { şekilde ölçeklendirilir }\end{array}$ & $1 / 20$ \\
\hline $\begin{array}{l}\text { Stopaj Vergi } \\
\text { Oranı } \\
\text { (Temettüler) }\end{array}$ & $\begin{array}{l}\text { [(yıllık maksimum stopaj vergi oranı - yıllık stopaj vergi oranı) / yıllık } \\
\text { maksimum stopaj vergi oranı] sıfır ile bir arasında ölçeklendirilir. Daha } \\
\text { yüksek bir değer daha cazip, yani daha düşük bir stopaj vergi oranını gösterir. }\end{array}$ & $1 / 20$ \\
\hline
\end{tabular}




\begin{tabular}{|c|l|c|c|}
\hline $\begin{array}{c}\text { Stopaj Vergi } \\
\text { Oranı }\end{array}$ & $\begin{array}{l}\text { [(yıllık maksimum stopaj vergi oranı - yıllık stopaj vergi oranı) / yıllık } \\
\text { maksimum stopaj vergi oran1] sifir ile bir arasında ölçeklendirilir. Daha }\end{array}$ & $1 / 20$ \\
(Faizler) & yüksek bir değer daha cazip, yani daha düşük bir stopaj vergi oranını gösterir. & \\
\hline $\begin{array}{c}\text { Stopaj Vergi } \\
\text { Oranı }\end{array}$ & $\begin{array}{l}\text { [(yıllık maksimum stopaj vergi oranı - yıllık stopaj vergi oranı) / yıllık } \\
\text { maksimum stopaj vergi oranı sifır ile bir arasında ölçeklendirilir. Daha }\end{array}$ & $1 / 20$ \\
(Telif Hakları) & yüksek bir değer daha cazip, yani daha düşük bir stopaj vergi oranını gösterir. & \\
\hline
\end{tabular}

Kaynak: Schanz, Keller, Dinkel, Fritz ve Grosselfinger, 2020.

Vergi çekicilik endeksi, içerisinde 20 bileşeni kapsadığından DYY kararları alırken firmalar için diğer vergi teşviklerine nazaran daha kapsamlı bir değerlendirmeyi ifade etmektedir. Çünkü yatırımlar için sağlanan vergi teşvikleri, vergi çekicilik endeksi içerisinde de yer almakta olup ayrıca DYY girişlerini belirleyebilecek bu endeks içerisinde, teşvikler harici uygulamalar (grup vergilendirme rejimleri, faiz indirimleri, çifte vergi anlaşması ağları, vergi ortamı vb.) da yer almaktadır. Küreselleşme ve süregelen ekonomik entegrasyonlarla birlikte hergeçen gün daha fazla şirket, uluslararası faaliyetlerini vergi yükünün daha az olduğu veya hiç olmadığı ülkelerde veya bölgelerde önemli ölçüde yoğunlaştırmak için çaba sarf etmektedirler. Firmalar yabancı ülkelerde iştirak kurup yatırım yapmak istediklerinde sadece ev sahibi pazarın büyüklügü̈, düşük faktör fiyatları ve piyasaya erişim gibi gerçek ekonomik faktörleri değil, aynı zamanda vergi kurallarının bütün ülkelerde uyumlu olmamasının çok uluslu şirketlere uluslararası farklılıklardan kendi yararlarına yararlanma firsatı sunan vergi çekiciliği endeksinin büyüklüğünü de dikkate almaktadırlar (Schanz, Dinkel ve Keller, 2017: 252). Çünkü son yıllarda, birçok ülkede sermaye kontrolleri ve döviz kısıtlamaları azaltılmış veya tamamen kaldırılmış olduğundan sermaye aktarımının vergi dışı maliyetleri dünya çapında düşmüştür. Sermaye aktarımında vergi dış1 maliyetler azaltıldığı için uluslararası sermayenin serbest akışına ülkeler arasındaki vergi uygulamalarından doğan farklılıklar yön vermeye başlamıştır. DYY'nin seviyesini ve varış noktasını belirlemede giderek daha önemli bir rol üstlenen ülkeler arasındaki vergisel farkl1lıklar, birçok ulusal hükümeti bu yatırımı çekmek için vergi politikasını kullanma konusunda daha agresif olmaya da teşvik etmiştir (Simmons, 2003: 105-106). Bu nedenle, DYY'yi artırmak amacıyla ülkeler yatırım geliri üzerinde önemli bir maliyet unsuru olan vergileri azaltabilmek için farklı teşviklere başvurmuşlardır. Ayrıca, bölgesel endüstriyel kalkınmayı sağlamak için de birçok ülke, yatırımları belirlenen bölgelere çekmek için o bölgelere özel ek teşvikler de sunmuştur (Tung ve Cho, 2000: 120). DYY girişileri ev sahibi ülke ekonomisini artıran en önemli uyarıcılardan biri olduğundan, ülke hükümetlerinin yabancı sermaye girişine büyük ilgi göstermesi ve yatırımcılar için elverişli koşullar oluşturmak amacıyla farklı türde ve oranda vergi teşvikleri uygulaması şaşırtıcı değildir (Ślusarczyk, 2018: 67). Çünkü beklenen çoklu kalkınma faydaları nedeniyle, DYY'yi çekmek birçok ülkede önemli bir politika hedefi olmuştur. Bu nedenle, DYY'leri çekmek için hükümetler mali teşvikler (indirimli kurumlar vergisi oranları gibi), finansal teşvikler (hibeler ve tercihli krediler gibi) ve tekel hakları; komşu ülkelerin zararlı rekabete girme olasılığını ifade eden "dibe doğru yarış" gibi farklı türde teşviklere başvurmuşlardır (Boly, Coulibaly ve Kéré, 2019: 1).

\section{Vergi Çekiciliği ve DYY İlişskisi: Literatür Taraması}

Ngowi (2000), daha fazla DYY çekmek için vergi teşvikleri verilmesinin farklı paydaşlar arasında karışık duygular ile karşılandığını belirtmiştir. Ayrıca DYY çekmek için verilecek vergi teşviklerinin, teşviklerin varlığı olmadan o ülkeye sermaye akışı sağlamayacak yabancı yatırımcıları çekmesi ve yatırımcılara verilen vergi teşviklerinin ülkeye geri dönüşler sunarak ülkenin kalkınmasına katkıda bulunması gerektiğini belirtmiştir.

Tung ve Cho (2000), özel vergi teşvik bölgelerinin oluşturulmasının DYY girişleri üzerinde etkili olup olmadığını Çin'deki 5 özel bölge için incelemişlerdir. 1991 yılında Çin'de özel bölgeler için imtiyazlı vergi oranları ve vergi teşvikleri uygulanmıştır. İmtiyazlı vergi oranlarının uygulanmasından önceki 3 yıl için özel vergi teşvik bölgelerindeki DYY'nin değerini, imtiyazlı vergi oranlarının uygulanmasından sonraki 3 yıl için DYY değeri ile karşılaştırmışlar ve imtiyazlı vergi 
oranları ve teşviklerin, DYY'yi Çin'deki belirlenmiş özel vergi teşvik bölgelerine çekmenin etkili bir yolu olduğunu tespit etmişlerdir. Bu sonuç özel teşvik bölgelerine DYY akışının artmasının, vergi sonrası yatırım getirisini artıran imtiyazlı vergi oranlarına ve teşviklerine atfedilebildiğini göstermektedir.

Simmons (2003), bir ülkenin kurumlar vergisi rejiminin DYY girişleri üzerinde önemli bir etkisi olup olmadığını 1999 yılı için 7 ülke (Singapur, Çin Halk Cumhuriyeti, Hong Kong, Avustralya, Kanada, İngiltere ve ABD) kapsamında incelemiştir. Bunun için öncelikle seçilen ülkelerin vergi sistemlerinin çeşitli nitelikleri hakkında uluslararası yatırımcıların ve vergi uzmanlarının değerlendirmeleri dikkate alınarak 1-10 arasında değișen bir endeks olușturmuș ve bu endeksin DYY girişleri üzerindeki etkisini analiz etmiştir. Yapılan analiz neticesinde DYY girişleri ile kurumlar vergisi çekicilik endeksi arasında pozitif ve anlamlı bir ilişki olduğunu tespit etmiştir.

Babatunde (2012), vergi teşvikleri, doğal kaynakların mevcudiyeti, makroekonomik istikrar, pazar büyüklüğü, ticari açıklık, altyapı gelişimi ve siyasi risk gibi seçilmiş faktörlerin Nijerya'daki petrol ve gaz sektöründeki DYY üzerindeki etkisini 1990-2010 dönemi kapsamında analiz etmiş ve vergi teşvikleri, doğal kaynakların mevcudiyeti ve ticari açıklığın Nijerya'daki petrol ve gaz sektöründeki DYY üzerinde önemli bir etkisi olduğunu, pazar büyüklüğü, makroekonomik istikrar, altyapı gelişimi ve politik riskin ise DYY üzerinde önemli bir etkisinin olmadığını tespit etmiştir.

Cristina (2012), vergi çekiciliğinin (doğrudan vergilendirmeyi temsil eden kurumlar vergisi oranını, dolaylı vergilendirmeyi temsil eden katma değer vergisini ve sosyal güvenlik katkı paylarını ve vergi ödeme kolaylığını içermektedir) Orta ve Doğu Avrupa ülkelerinin yabancı yatırımcılar için çekiciliğini etkileyip etkilemediğini, 2007-2010 yılları kapsamında analiz etmiştir. Analiz neticesinde vergi çekiciliği ile DYY arasında mükemmel bir uyum bulunmadığını, DYY girişleri üzerinde daha yüksek etkiye sahip başka faktörler (makroekonomik istikrar, altyapı, kurumsal çevre gibi diğer DYY belirleyicileri) olduğunu tespit etmiştir. Ayrıca vergi sorunuyla mücadele ederek vergi ödeme yükünü hafifletmenin, bir ülkenin DYY çekiciliğini artırmanın bir aracı olduğunu da belirtmiştir.

OECD (2013), DYY girişlerinin artırılması için sadece vergi oranlarının değil, çifte vergilendirme sözleşmeleri de dâhil olmak üzere tüm vergi sisteminin dikkate alınmasının önemini vurgulamıştır.

Dinkel, Keller ve Schanz (2014), ev sahibi ülkenin vergi çekicilik endeksi tarafindan ölçülen vergi ortamının, o ülkede bulunan Alman kontrolündeki bağlı ortaklıklarının sayısını belirlemede önemli bir rol oynayıp oynamadığını araştırmışlar ve bir ülkenin vergi çekiciliğinin iştirak sayısı üzerinde olumlu bir etkisi olduğunu ortaya koymuşlar ve firmaların yer seçiminin birden çok vergi faktörüne bağlı olduğunu belirlemişlerdir. Ayrıca çokuluslu işletmelerin yer kararlarının sadece yasal vergi oranı ile açıklanamayacağını, kurumlar vergisi oranı bir ülkedeki iştiraklerin sayısı üzerinde önemli bir etkiye sahip olsa da, konum kararlarının vergi çekicilik endeksinde bir araya getirilen bir grup vergi faktörü ile daha iyi açılanabileceğini ifade etmişlerdir.

Dinkel (2015), ülkelerin vergi çekiciliğinin çokuluslu şirketlerin coğrafi risk dağılımı üzerinde etkisi olup olmadığını araştırmıştır. Araştırma 90 farklı ülkeden ebeveynlere ait olan 12.255 çokuluslu grup içeren toplam 110.391 şirket üzerine yapılmıştır. Vergi çekiciliği olarak ülkelerdeki kurumlar vergisi oranı, zararların geriye doğru uygulanabilmesi ve zararların ileriye taşınması kriterlerini kullanmıştır. Çalışmanın neticesinde cari dönem zararları, grup ortalamasına kıyasla ne kadar uzun süre geriye veya ileriye alınabilirse, bağlı ortaklığın o kadar fazla risk alabildiğini, ancak grup ortalamasından daha yüksek bir yasal vergi oranının ise bağlı ortaklığın nispeten daha az risk almasına yol açtığını tespit etmiştir.

Dinkel ve Schanz (2015), patentlerin çokuluslu şirketler içindeki yerinin belirlenmesinde vergi çekiciliğinin etkisi olup olmadığını 36 ülkenin 2005-2012 verilerini kullanarak regresyon 
analizi ile incelemişlerdir. Analizde vergi çekiciliği olarak yasal kurumlar vergisi oranı, Ar-Ge vergi teşviki, telif ücretlerinin vergilendirilmesi, transfer fiyatlandırması ve Keller ve Schanz'in kullandığ 1 16 bileşene 3 bileşen daha ekleyerek oluşturdukları genel vergi çekiciliği endeksini kullanmışlardır. Çalışmanın neticesinde çok uluslu şirketlerin patent kararları verirken ülkelerin vergi çekiciliğini dikkate aldıklarını, özellikle yasal vergi oranının, telif ücretlerinin vergilendirilmesinin, Ar-Ge teşviklerinin ve transfer fiyatlandırması kurallarının çok uluslu şirketlerin patent-yer seçimlerini açıklamaya yardımcı olduğunu tespit etmişlerdir.

Lodhi (2017), teşvik politikasının (kurumlar vergisi oranı ve tarife oranları) Pakistan'daki yatırımlar (DYY ve yurtiçi yatırım) üzerindeki etkisini 1990-2014 verilerini kullanarak ARDL ve regresyon yöntemleri ile analiz etmiştir. Çalışmanın neticesinde kurumlar vergisi oranındaki düşüşün DYY ve yurtiçi yatırımlarda önemli artışlara katkı sağladığını, ancak ithalat tarife oranlarının DYY veya yerli yatırım ile istatistiksel olarak anlamlı bir ilişkiye sahip olmadığını belirtmiştir. Ayrıca vergi politikalarının rekabet gücü, şeffaflık, tutarlılık ve rasyonelleştirilmesi yoluyla yatırımcılara yatırım dostu ortamın sağlanabileceğini öne sürmüştür. Vergi politikasının sadece gelir tahsilatı üzerine odaklanması gerektiği değil, aynı zamanda ülkenin genel ekonomik göstergelerinin iyileşmesine yol açacak yatırımların teşvik edilmesine yardımcı olacak şekilde bütünsel bir bakış açısıyla planlanması ve uygulanması gerektiğini de vurgulamıştır.

Schanz, Dinkel ve Keller (2017), vergilendirmenin çok uluslu işletmelerin yer kararlarında ve belirli bir ülkedeki iştirak sayısı üzerinde bir etkisi olup olmadığını 97 ülkedeki Alman DAX301 şirketlerinin iştiraklerinden oluşan şirketler için regresyon analizi ile incelemişlerdir. Analizde Alman DAX30 şirketlerinin 2005-2009 yılları arasındaki iştiraklerinden oluşan veri kümesini kullanmışlardır. Vergi dışı etkileri kontrol ederek, bir ülkenin vergi ortamının Alman kontrolündeki bağlı ortaklıklarının sayısı ve dolayısıyla Alman çokuluslu işletmelerinin konum kararları üzerinde önemli ölçüde olumlu bir etkiye sahip olduğunu belirlemişlerdir. Ayrıca vergi çekicilik endeksinin, çokuluslu işletmelerin konum kararları için yaygın olarak kullanılan model tabanlı etkili vergi oranlarından daha yüksek bir açıklayıcı güce sahip olduğunu belirlemişlerdir.

Şaşmaz ve Bayar (2017), mali teşviklerin kısa ve uzun dönemde DYY çekmede etkisinin olup olmadığını Türkiye için 2006-2016 verilerini kullanarak ARDL eşbütünleşme ve TodaYamamoto (1995) nedensellik testleri ile araştırmışlar ve DYY girişleri ile mali teşvikler arasında kısa dönemli bir ilişkinin olmadığı, ancak mali teşviklerin uzun dönemde DYY girişlerini pozitif etkilediğini tespit etmişlerdir. Tahmin edilen sonuç itibariyle mali teşviklerin DYY girişleri üzerindeki etkisinin kısa dönemde de etkili olabilmesi bu teşviklerin kurumsal gelişmişlik, ekonomik büyüme ve siyasi ve ekonomik istikrar gibi unsurlarla desteklenmesi gerektiğini belirtmişlerdir.

Thuita (2017), vergi teşviklerinin (özellikle vergi tatili ve sermaye kesintilerinin) ihracat işleme bölgelerindeki DYY çekiciliğini ve elde tutmayı nasıl etkilediğini, Kenya için ihracat işleme bölgesinde faaliyet gösteren firmaların çalışanları (72) üzerine yaptığı anket çalışması ile araştırmıştır. Vergi tatili uygulamasının DYY cazibesini ve elde tutulmasını büyük ölçüde etkilediğini, imalat sektörünün de genişletilmiş sermaye indirimleri nedeniyle diğer sektörlere kıyasla dah fazla tercih edildiğini ortaya koymuştur. Yabancı sermaye yatırımlarının büyümesini ve genişlemesini artırmak için de vergi teşviklerinin artırılması gerektiğini ve hükümetin vergi tatili uygulamasını on yılı aşkın bir şekilde uygulayacağı hususunda, uzun vadeli yatırımcılar için istekli olması gerektiğini belirtmiştir.

Ślusarczyk (2018), Polanya hükümeti tarafında Özel Ekonomik Bölgelerdeki yatırımcılara yönelik verilen devlet yardımının ve belediyeler tarafından sunulan emlak vergisi muafiyetinin DYY girişleri üzerindeki etkisini 2004-2016 dönemi kapsamında incelemiş ve gelir vergisi ve emlak

\footnotetext{
${ }^{1}$ DAX30, Almanya'nın en büyük borsa endeksi olup sipariş defteri hacmine ve piyasa değerine göre listelenen en büyük 30 şirketi içermektedir.
} 
vergisinden muafiyet şeklinde sunulan vergi muafiyetlerinin, DYY girişini belirleyen önemli faktörler olduğunu tespit etmiştir.

Alves (2019), vergi sistemlerinin yatırımlar üzerindeki etkisini OECD ülkeleri için 19802015 dönemi kapsamında incelemiş ve vergi gelirlerinin GSMH'ya oranının hangi eşikte olması gerektiğini belirlemiştir. Uzun vadeli yatırım büyümesinin teşvik edilmesi için kısa vadede, bireysel gelir üzerinden alınan vergiler için eșik değerinin azami \%10.65, mal ve hizmetler üzerinden alınan vergiler ve kurumlar üzerinden alınan vergiler için eşik değerinin sırasıyla ortalama \%14.18 ve $\% 7.37$, sosyal güvenlik paylarınında ise eşik değerinin minimum \%12.09 olması gerektiğini tespit etmiştir. Uzun vadede ise mal ve hizmetler üzerinden alınan vergiler ve kurumlar üzerinden alınan vergiler için eşik değerinin sırasıyla maksimum $\% 9.19$ ve $\% 6.27$, sosyal güvenlik paylarınında ise eşik değerinin minimum \%11.35 olması gerektiğini tespit etmiştir

Boly vd. (2019), kurumlar vergisi oranlarındaki indirimlerin DYY çekmedeki etkinliğini 1990-2012 döneminde 19 Afrika ülkesin için dengeli bir panel modeli ile incelemişler ve kurumlar vergisi oranındaki kesintilerin kısa ve uzun vadede ev sahibi ülkeye ve diğer komşu ülkelere DYY girişlerini artırdığını tespit etmişlerdir. Bununla birlikte, daha düşük vergi gelirlerinin olumsuz etkilerini azaltmak için, hükümetlerin vergi tabanını genişletmelerini ve kalkınma ihtiyaçlarını finanse etmek için vergi toplama kapasitelerini güçlendirmeleri gerektiğini ifade etmişlerdir.

Hsu vd. (2019), vergi teşvikinin yabancı yatırım kararlarının önemli bir belirleyicisi olup olmadığını Çin'deki eyaletler için 1998-2008 dönemi kapsamında GMM panel veri yöntemi ile analiz etmişler. Pazar büyüklüğü ve coğrafi faktörlerin incelenen dönemler boyunca Çin'de DYY girişleri üzerinde önemli bir etkisi olduğunu, vergi teşviklerinin ise etkisinin olumlu olmasına rağmen istatistiksel olarak anlamlı olmadığını tespit etmişlerdir. Bu yüzden de Çin'de DYY için tercihli vergi politikaları uygulamalarının 2008 yılında sonlandırıldığını ifade etmişlerdir.

Tahlova ve Banociova (2019), kurumlar vergisi gelirlerinin vergi ve vergi dışı belirleyicilerini 2007-2016 y1lları kapsamında AB-28 ülkeleri özelinde incelemişlerdir. Analiz neticesinde vergi belirleyicisi olarak kurumlar vergisinin yasal oranındaki artışın, vergi dışı belirleyici olarak da uluslararası faktörler olarak nitelendirilen DYY'lerin, vergi çekiciliğinin ve küreselleşmenin kurumlar vergisi gelirlerini artırdığını tespit etmişlerdir.

Uras vd. (2019), mali teşviklerin doğrudan yabancı sermaye yatırımları üzerindeki etkisini Türkiye için 2005-2018 aylık verileri kullanarak toda-yamamoto nedensellik testi ile araştırmışlar ve değişkenler arasında çift yönlü nedensellik ilişkisi olduğunu tespit etmişlerdir.

\section{Analiz}

Çalışmada, zaman serisi ve yatay kesit modellerine göre daha geniş veri seti sunması, bu bağlamda daha güvenilir tahminler vermesi ve bireysel heterojenliği kontrol altına alma avantajları nedeniyle panel veri modeli kullanılmıştır. Çalışmanın kapsamı belirlenirken dünya bankası tarafindan yapılan ülke sınıflandırması tercih edilmiş ve verilerine ulaşılabilen gelişmiş ve gelişmekte olan ülkelere (Ek 1' de belirtilmiştir) ait 2007-2018 yılları arası verileri kullanılmıştır. Vergi çekiciliği endeksi (Ek 2 ve Ek 3'de 2018 yll vergi çekicilik endeksi ve bileşenleri belirtilmiştir) 2007 yılından itibaren düzenli bir şekilde yıllık olarak yayınlandığ 2007 olarak belirlenmiştir. Çalışmada bağımlı değişken olarak DYY girişlerinin GSYH'ya oranı (FDI), bağımsız değişken olarak vergi çekiciliği endeksi (TAI), kontrol değişkenler olarak ise ekonomik özgürlük endeksi (EFI), kişi başı milli gelirdeki değişim (GDP PPP) ve ticari açıklık/GSMH oranı (TO) kullanılmıştır. DYY, kişi başı milli gelirdeki değişim ve ticari açıklık verileri (https://data.worldbank.org/), vergi çekicilik endeksi (https://www.tax-index.org/) ve ekonomik özgürlük endeksi (https://www.heritage.org/index/explore) web sayfalarından elde edilmiştir. Çalışmada vergi çekiciliğinin ve diğer kontrol değişkenlerin DYY girişleri üzerindeki 
etkisi, gelişmiş ve gelişmekte olan ülkeler için ayrı modeller kapsamında Stata 15.0 programı kullanılarak tahmin edilmiştir.

$$
(\mathrm{FDI})_{\mathrm{it}}=\beta_{0}+\beta_{1} \cdot \mathrm{TAI}_{\mathrm{it}}+\beta_{2} \cdot \mathrm{EFI}_{\mathrm{it}}+\beta_{3} \cdot \mathrm{GDP} P P P_{\mathrm{it}}+\beta_{4} \cdot \mathrm{TO}+\mathrm{u}_{\mathrm{it}}
$$

Yukarıda modelde yer alan $i$; çalışmada ele alınan ülkeleri, $t$ ise zamanı göstermekte olup verilere ilişkin özet istatistikler Tablo 2'de belirtilmiştir.

Tablo 2: Gelişmiş/Gelişmekte Olan Ülkeler İçin Özet İstatistikler

\begin{tabular}{|c|c|c|c|c|c|}
\hline & \multicolumn{5}{|c|}{ Gelişmiş Ülkeler } \\
\cline { 2 - 6 } & FDI & TAI & TO & EFI & GDP PPP \\
\hline Ortalama & 5.31 & 0.46 & 108.36 & 71.38 & 1.32 \\
\hline Standart Sapma & 11.24 & 0.15 & 70.74 & 6.90 & 3.37 \\
\hline Basıklık & 17.61 & 1.92 & 5.92 & -0.20 & 6.71 \\
\hline Çarpıklık & 2.43 & 1.03 & 2.23 & -0.01 & 0.00 \\
\hline En Küçük & -58.32 & 0.14 & 24.49 & 53.20 & -14.27 \\
\hline En Büyük & 86.61 & 0.92 & 437.33 & 89.40 & 23.99 \\
\hline & \multicolumn{5}{|c|}{ Gelişmekte Olan Ülkeler } \\
\hline Ortalama & FDI & TAI & TO & EFI & GDP PPP \\
\hline Standart Sapma & 3.57 & 0.38 & 76.83 & 59.41 & 2.70 \\
\hline Basıklık & 3.69 & 0.08 & 34.57 & 6.97 & 3.28 \\
\hline Çarpıklık & 23.98 & -0.30 & 0.40 & -0.45 & 2.24 \\
\hline En Küçük & 3.70 & -0.13 & 0.77 & -0.03 & -0.68 \\
\hline En Büyük & -6.06 & 0.15 & 20.72 & 43.80 & -14.38 \\
\hline
\end{tabular}

Gelişmiş ve gelişmekte olan ülkeler için DYY girişleri üzerinde vergi çekiciliğinin etkisinin araştırılması için kurulacak panel veri modellerinde, tüm serilerin durağan olması gerekmektedir. Bu amaçla yapılacak panel birim kök testleri, modelde yatay kesit bağımlılı̆̆ının var olup olmamasına bağlı olarak farklılaşmaktadır. Bu nedenle öncelikle modelde yatay kesit bağımlılığının var olup olmadığ 1 Pesaran (2004) Cross-section Dependence (CD) testi ile test edilmiş ve sonuçlar Tablo 3 'de belirtilmiştir. Panel veri yapısında zaman boyutu (T) 12 olduğundan ve bu zaman boyutu panel birim sayısından $(\mathrm{N}=41)$, küçük olduğundan $\mathrm{T}<\mathrm{N}$ koşulu sağlanmaktadır. Bu durumda Pesaran 2004 yatay kesit bağımlılık testi daha tutarlı sonuçlar verdiğinden bu test tercih edilmiştir. Pesaran 2004 testi sonucunda gelişmiş ülkeler için katsayı (6.99) ve olasılık değeri (0.00) olarak hesaplanmıştır. Gelişmekte olan ülkeler için ise Pesaran 2004 testi sonucunda katsayı (6.28) ve olasılık değeri (0.00) olarak hesaplanmıştır. Sonuçta olasılık değerleri 0.01'den küçük olduğundan her iki ülke modeli için yatay kesit bağımlılığının olmadığı $\left(\mathrm{H}_{0}\right.$ : Yatay kesit bağımlılığı yoktur) boş hipotezi \%99 güven aralığında reddedilerek modelde yatay kesit bağımlılığının olduğu sonucuna varılmıştır.

Tablo 3: Yatay Kesit Bağımlılık Testi

\begin{tabular}{|c|c|c|c|c|c|c|}
\hline Değişkenler & \multicolumn{3}{|c|}{ Gelişmiş Ülkeler } & \multicolumn{3}{c|}{ Gelişmekte Olan Ülkeler } \\
\hline FDI & Katsay1 & Std. Hata & p-değeri & Katsay1 & Std. Hata & p-değeri \\
\hline TAI & 37.36 & 15.44 & 0.02 & -1.95 & 3.91 & 0.62 \\
\hline TO & -0.08 & 0.04 & 0.02 & 0.04 & 0.01 & 0.00 \\
\hline EFI & -0.34 & 0.24 & 0.16 & -0.16 & 0.05 & 0.00 \\
\hline GDP PPP & 0.47 & 0.15 & 0.00 & 0.13 & 0.04 & 0.00 \\
\hline Sabit & 20.56 & 18.17 & 0.26 & 10.15 & 3.20 & 0.00 \\
\hline F-Test & 4.72 & --- & --- & 11.11 & --- & -- \\
\hline
\end{tabular}


Vergi Çekiciliğinin Doğrudan Yabancı Yatırım Girişlerine Etkisi: Gelişmiş ve Gelişmekte.... 865

\begin{tabular}{|c|c|c|c|c|c|c|}
\hline CD Testi & 6.99 & --- & 0.00 & 6.28 & --- & 0.00 \\
\hline Gözlem sayısı & \multicolumn{3}{|c|}{492} & \multicolumn{3}{|c|}{504} \\
\hline $\mathrm{N}$ & \multicolumn{3}{|c|}{41} & \multicolumn{3}{|c|}{42} \\
\hline $\mathrm{T}$ & \multicolumn{3}{|c|}{12} & \multicolumn{3}{|c|}{12} \\
\hline
\end{tabular}

Modelde yatay kesit bağımlılığı tespit edildiği için panel birim kök testleri içerisinde yer alan ve yatay kesit bağımlılı̆̆ını dikkate alan ikinci kuşak testlerinden Pesaran 2007 panel birim kök testinin uygulanmasına karar verilmiştir. Panel birim kök testi modeldeki bağımlı ve bağımsız değişkenlere sabitli ve sabitli-trendli modeller şeklinde uygulanmış olup sonuçlar Tablo 4'de belirtilmiştir. Elde edilen sonuçlarda seriler düzeyde durağan olduğu için bu seriler I(0) olarak kabul edilmiştir.

Tablo 4: Pesaran 2007 Panel Birim Kök Testi

\begin{tabular}{|c|c|c|c|c|c|c|c|c|}
\hline & \multicolumn{4}{|c|}{ Gelişmiş Ülkeler } & \multicolumn{3}{c|}{ Gelişmekte Olan Ülkeler } \\
\hline \multirow{2}{*}{ Değişkenler } & \multicolumn{2}{|c|}{ Sabitli } & \multicolumn{2}{|c|}{ Sabitli ve Trendli } & \multicolumn{2}{c|}{ Sabitli } & \multicolumn{2}{c|}{ Sabitli ve Trendli } \\
\cline { 2 - 9 } & $\mathrm{t}$ ist. & Prob. & $\mathrm{t}$ ist. & Prob. & $\mathrm{t}$ ist. & Prob. & $\mathrm{t}$ ist. & Prob. \\
\hline FDI & -2.85 & $0.00^{* * *}$ & -3.26 & $0.05^{*}$ & -2.87 & $0.00^{* * *}$ & -3.15 & $0.00^{* * *}$ \\
\hline TAI & -3.04 & $0.00^{* * *}$ & -3.39 & $0.00^{* * *}$ & -2.74 & $0.00^{* * *}$ & -3.16 & $0.00^{* * *}$ \\
\hline TO & -2.58 & $0.00^{* * *}$ & -2.74 & $0.00^{* * *}$ & -2.50 & $0.00^{* * *}$ & -3.12 & $0.00^{* * *}$ \\
\hline EFI & -3.19 & $0.00^{* * *}$ & -3.44 & $0.00^{* * *}$ & -2.24 & $0.00^{* * *}$ & -2.46 & $0.01^{* *}$ \\
\hline GDP PPP & -2.42 & $0.00^{* * *}$ & -2.58 & $0.03^{* *}$ & -2.07 & $0.02^{* *}$ & -2.51 & $0.08^{*}$ \\
\hline
\end{tabular}

Not: $* * * * *$ ve $*$ sirasiyla $\% 1, \% 5$ ve $\% 10$ anlamlllık düzeylerini ifade etmektedir.

Çalışmada kullanılan serilere ilişsin panel birim kök testleri yapıldıktan sonra model oluşturma aşamasında sabit etkiler modeli ile rassal etkiler modeli arasında seçim yapmak için Hausman testi kullanılmış ve sonuçlar Tablo 5'te belirtilmiştir. Bu amaçla

$\mathrm{H}_{0}$ : Birey etkileri rassaldır,

$\mathrm{H}_{1}$ : Birey etkileri sabittir, hipotezleri test edilmiştir.

Gelişmiş ülkeler için ilgili test istatistiği olasılık değeri 0,00 olarak hesaplandığından boş hipotez \%99 güven düzeyinde reddedilmiştir. Dolayısıyla analizin devamında sabit etkiler modeli kullanılmıştır. Gelişmekte olan ülkeler için ise ilgili test istatistiği olasılık değeri 0,26 olarak hesaplandığından boş hipotez \%90 güven düzeyinde reddedilememiştir. Dolayısıyla analizin devamında rassal etkiler modeli kullanılmıştır.

Tablo 5: Hausman Testi Sonucu

\begin{tabular}{|c|c|c|c|c|c|c|c|c|}
\hline \multirow{2}{*}{ Değişken } & \multicolumn{4}{|c|}{ Gelişmiş ülkeler } & \multicolumn{4}{c|}{ Gelişmekte olan ülkeler } \\
\cline { 2 - 9 } & S.E & R.E & Fark & $\begin{array}{c}\text { Standart } \\
\text { Hata }\end{array}$ & S.E & R.E & Fark & Standart Hata \\
\hline TAI & 2.11 & -3.43 & 5.55 & 2.58 & 0.61 & 2.73 & -2.11 & 2.24 \\
\hline TO & 0.01 & 0.01 & 0.00 & 0.00 & -0.01 & -0.02 & 0.00 & 0.00 \\
\hline EFI & - & -0.19 & 0.02 & 0.02 & -0.11 & -0.04 & -0.07 & 0.03 \\
\hline GDP PPP & 0.17 & 0.38 & -0.02 & 0.02 & 0.10 & 0.10 & 0.00 & 0.01 \\
\hline \multicolumn{2}{|c|}{ Test Özeti } & $\begin{array}{c}\text { Ki-kare } \\
\text { İstatistiği }\end{array}$ & $\begin{array}{c}\text { Ki-kare } \\
\text { d.f. }\end{array}$ & Olasılık & Test Özeti & $\begin{array}{c}\text { Ki-kare } \\
\text { İstatistiği }\end{array}$ & $\begin{array}{c}\text { Ki- } \\
\text { kare. } \\
\text { d.f. }\end{array}$ & Olas1lık \\
\hline $\begin{array}{c}\text { Kesitler Aras1- } \\
\text { Rassal }\end{array}$ & 22,12 & 4 & 0,00 & $\begin{array}{c}\text { Kesitler } \\
\text { Arasi-Rassal }\end{array}$ & 5,24 & 4 & 0,26 \\
\hline
\end{tabular}


Durağan değişkenlerle birlikte standart model oluşturulmuş ve standart modele ilişkin değişen varyans, otokorelasyon ve yatay kesit bağımlılığının varlığı test edilmiştir. Modellerde değişen varyans, otokorelasyon ve yatay kesit bağımlılık problemlerinin olup olmadığı gelişmiş ülkeler için sırasıyla Değiştirilmiş Wald (2001), Wooldridge (2002) ve Pesaran (2004) CD testleri ile test edilmişken, gelişmekte olan ülkeler için ise sırasıyla LR, Wooldridge (2002) ve Pesaran (2004) CD testleri ile test edilmiştir. Wald test istatistiği olasılık değeri $(p=0.00)$ ve LR test istatistiği olasılık değeri $(\mathrm{p}=0.00)$ olarak tespit edilmiştir. Buna göre modelde değişen varyans sorunun olmadığ $\mathrm{b}$ boş hipotez $\left(\mathrm{H}_{0}\right.$ : Değişen varyans yoktur) \%99 güven aralığında reddedilmiştir. Wooldridge test istatistiği olasılık değeri gelişmiş ve gelişmekte olan ülkeler için $(\mathrm{p}=0.00)$ olarak hesaplanmıştır. Buna göre modelde otokorelasyon sorunun olmadığ boş hipotez $\left(\mathrm{H}_{0}\right.$ : Otokorelasyon yoktur) \%99 güven aralığında reddedilmiştir. Pesaran 2004 Yatay Kesit Bağımlılık Testi test istatistiği olasılık değeri de her iki ülke grubu için $(\mathrm{p}=0.00)$ olarak hesaplanmıştır. Buna göre modelde yatay kesit bağımlılığı sorunun olmadığı boş hipotez $\left(\mathrm{H}_{0}\right.$ : Yatay kesit bağımlılığı yoktur) \%99 güven aralığında reddedilmiştir. Sonuç olarak kurulan ilk sabit etkili panel veri modelinde değişen varyans, otokorelasyon ve yatay kesit bağımlılık sorunlarının olduğu tespit edilmiştir. Mevcut değişen varyans, otokorelasyon ve yatay kesit bağımlılık sorunlarının çözümü için Driscoll Kraay standart hatalı model kullanılarak model yeniden tahmin edilmiş olup sonuçlar Tablo 6'da belirtilmiştir.

Tablo 6: Gelişmiş ve Gelişmekte Olan Ülkeler İçin Panel Veri Modeli Tahmin Sonuçları

\begin{tabular}{|c|c|c|c|c|c|c|c|}
\hline \multicolumn{8}{|c|}{ Gelişmiş Ülkeler İçin Tahmin Sonuçları } \\
\hline \multirow{2}{*}{\multicolumn{2}{|c|}{ Bağımlı Değişken: FDI }} & \multicolumn{3}{|c|}{ Standart Model } & \multicolumn{3}{|c|}{ Driscoll Kraay Standart Hatalı } \\
\hline & & Katsayı & Std. Hata & P-değeri & Katsay 1 & Std. Hata & P-değeri \\
\hline \multicolumn{2}{|c|}{ TAI } & 2.1109 & 22.3342 & 0.0525 & 2.1109 & 15.6420 & $0.0495 * *$ \\
\hline \multicolumn{2}{|c|}{ TO } & 0.0050 & 0.0442 & 0.0909 & 0.0050 & 0.0630 & $0.0938^{*}$ \\
\hline \multicolumn{2}{|c|}{ EFI } & 0.1659 & 0.2900 & 0.0568 & 0.1659 & 0.2372 & $0.0500 * *$ \\
\hline \multicolumn{2}{|c|}{ GDP PPP } & 0.3612 & 0.1396 & 0.0100 & 0.3612 & 0.3304 & 0.3000 \\
\hline \multicolumn{2}{|c|}{ Sabit } & 4.5553 & 0.4167 & 0.0000 & 4.5553 & 0.7177 & $0.0000 * * *$ \\
\hline $\mathrm{R}^{2}$ & F-Testi & Wald Testi & $\begin{array}{c}\text { Wooldridge } \\
\text { Testi }\end{array}$ & $\begin{array}{c}\text { Pesaran } 2004 \\
\text { CD Testi }\end{array}$ & $\mathrm{R}^{2}$ & \multicolumn{2}{|c|}{ F-Testi } \\
\hline 0.592 & $\begin{array}{c}1.9700 \\
(0.0977) \\
\end{array}$ & $\begin{array}{l}1500000 \\
(0.0000) \\
\end{array}$ & $\begin{array}{l}12.8600 \\
(0.0009) \\
\end{array}$ & $\begin{array}{c}9.7590 \\
(0.0000) \\
\end{array}$ & 0.592 & \multicolumn{2}{|c|}{$0.7700(0.5710)$} \\
\hline \multicolumn{8}{|c|}{ Gelişmekte Olan Ülkeler İçin Tahmin Sonuçları } \\
\hline \multirow{2}{*}{\multicolumn{2}{|c|}{ Bağımlı Değişken: FDI }} & \multicolumn{3}{|c|}{ Standart Model } & \multicolumn{3}{|c|}{ Driscoll Kraay Standart Hatalı } \\
\hline & & Katsay 1 & Std. Hata & P-değeri & Katsay 1 & Std. Hata & P-değeri \\
\hline \multicolumn{2}{|c|}{ TAI } & 2.7272 & 3.1036 & 0.0380 & 2.7272 & 1.5852 & $0.0116^{* *}$ \\
\hline \multicolumn{2}{|c|}{ TO } & 0.0170 & 0.0152 & 0.0264 & -0.0170 & 0.0292 & $0.0574 *$ \\
\hline \multicolumn{2}{|c|}{ EFI } & 0.0427 & 0.0374 & 0.0253 & -0.0427 & 0.0365 & $0.0269 * *$ \\
\hline \multicolumn{2}{|c|}{ GDP PPP } & 0.1020 & 0.0381 & 0.0070 & 0.1020 & 0.0463 & $0.0520^{*}$ \\
\hline \multicolumn{2}{|c|}{ Sabit } & 4.6278 & 2.4597 & 0.0600 & 4.6278 & 2.7594 & 0.1240 \\
\hline $\mathrm{R}^{2}$ & F-Test & LR Test & $\begin{array}{c}\text { Wooldridge } \\
\text { Test }\end{array}$ & $\begin{array}{c}\text { Pesaran } 2004 \\
\text { CD Testi }\end{array}$ & $\mathrm{R}^{2}$ & \multicolumn{2}{|c|}{ F-Test } \\
\hline 0.653 & $\begin{array}{c}9.6000 \\
(0.0477)\end{array}$ & $\begin{array}{c}636.2400 \\
(0.0000)\end{array}$ & $\begin{array}{c}8.42 \\
(0.0059)\end{array}$ & $\begin{array}{c}11.07 \\
(0.0000)\end{array}$ & 0.653 & \multicolumn{2}{|c|}{$7.0800(0.1318)$} \\
\hline
\end{tabular}

Not: Parentez içersindeki değerler olasılık değerlerini ifade etmektedir.

Değişen varyans, otokorelasyon ve yatay kesit bağımlılığının varlı̆̆ını dikkate alarak yapılan Driscoll Kraay standart hatalı model tahmin sonuçlarına göre gelişmiş ülkelerde bağımsız değişken olan vergi çekiciliği endeksinin, kontrol değişkenler olan ticari açıklığın ve ekonomik özgürlük endeksinin DYY girişleri üzerindeki etkisi pozitif ve anlamlı bulunmuşken, kişi başına düşen 
GDP'deki değişim oranının ise etkisi pozitif ancak anlamsız bulunmuştur. Gelişmekte olan ülke grubunda ise bütün değişkenlerin DYY girişleri üzerindeki etkisi pozitif ve anlamlı bulunmuştur. Bu durum gelişmiş ve gelişmekte olan ülke gruplarında firmaların yabancı ülkelerde yatırım yapması üzerinde vergi çekiciliği ortamının oldukça faydalı etkilerinin olduğunu göstermektedir. Ayrıca tahmin sonuçlarında vergi çekiciliğininde meydana gelen 1 birimlik artışın gelişmekte olan ülkelerde (2.72) DYY girişlerini, gelişmiş ülkelere (2.11) göre daha fazla artırdığı sonucu elde edilmiştir. Elde edilen tahmin sonuçları gelişmekte olan ülkelerin, gelişmiş ülkelere nazaran DYY giriş eksikliğini göstermekte olup vergi çekiciliğinde meydana gelecek her bir iyileşmenin DYY girişlerini artıracağını göstermektedir.

\section{Sonuç}

Çalışmada birçok teşvik kalemini içeren vergi çekiciliğinin DYY girişleri üzerindeki etkisi 2007-2018 dönem verileri kullanılarak gelişmiş ve gelişmekte olan ülke grupları için panel veri analizi ile incelenmiştir. Vergi çekiciliği endeksi 2007 yılından itibaren yıllık olarak yayınlandığı için başlangıç yılı olarak bu yıl tercih edilmiştir. Ayrıca DYY girişleri üzerinde etkisi olabilecek ticari açıklık, ekonomik özgürlük endeksi ve kişi başına düşen milli gelirdeki artış verileri de modele dâhil edilmiştir. Gelişmiş ve gelişmekte olan ülkeler için kurulan modelde yatay kesit bağımlılı̆̆ 1 bulunduğu için değişkenlerdeki birim kökün varlığ 1 Pesaran (2007) ile yapılmıştır. Daha sonrasında yapılan hausman testi ile gelişmiş ülkelerde sabit etkili modelin, gelişmekte olan ülkelerde ise rassal etkili modelin uygulanmasına karar verilmiştir. Modellerde değişen varyans, otokorelasyon ve yatay kesit bağımlılığ 1 olduğu tespit edildiği için analiz Driscoll Kraay testi ile tahmin edilmiştir. Çalışmanın neticesinde vergi çekiciliğinin her iki ülke grubunda da DYY girişleri üzerindeki etkisi pozitif ve istatistiki olarak anlamlı bulunmuştur. Politika yapıcılar bu bilgiyi, konumun çekiciliğini artırmak için hedeflenebilecek gelecekteki vergi reformları için kullanabilirler. Diğer kontrol değiş̧kenlerden ise kişi başına düşen milli gelirdeki artışın gelişmiş ülkelerde DYY girişleri üzerindeki etkisi istatistiki olarak anlamsız bulunmuşken diğer değişkenlerin etkisi pozitif ve anlamlı bulunmuştur. Yabancı sermeye yatırımları, sadece uzun vadede tüketime değil, aynı zamanda sürdürülebilir bir büyüme yoluna, istihdam artışına, teknolojik gelişmeye, rekabet ortamında katma değeri yüksek ürünlerin üretilmesine ve hizmetlerin geliştirilmesine ve bilgi akışına da katkı sağlayabileceği için hükümetler tarafından teşvik edilmektedir. Ülkelerin bu yatırımların kendi ülkelerinde yapılması için sağlamış oldukları teşvik politikası ise zamanla bu ülkelerin birbiriyle yarışır hale gelmesine zemin hazırlamış ve ülkeler arasında DYY girişlerin de vergi rakabeti yaşanmaya başlamıştır.

Küreselleşme ile birlikte artan rekabetçilik ve rasyonel vergi politikaları ile yatırımcılara yatırım dostu bir ortam sağlayabilmek adına gelişmiş ve gelişmekte olan bütün ülkeler, DYY kararları üzerinde önemli bir maliyet unsuru olan vergi yükünü azaltmak amaciyla ülkedeki genel ekonomik kalkınmayı sağlamak için ekonomi politikasının bir bileşeni olan farklı teşvik araçlarına başvurmaktadırlar. Ancak DYY çekmek için ülkeler tarafindan sağlanan bu farklı teşvik uygulamaları vergi rekabetine dönüştügünnde, ülkeler belirli bir getiri bekledikleri DYY yatımlarından olumsuz etkilenebilirler. Çünkü bu yatırımları çekmek için sağlanan vergisel teşvikler bir vergi harcamasını ifade etttiği için, ülkeler arasındaki vergi rekabetinin artması daha fazla vergi harcamas1 yapılmasina neden olabilecek ve bu harcamanın tutarı, DYY getirisinden fazla olabileceğinden ekonominin büyümesine katk1 sağlamayacaktır. Bu yüzden ülkelerinde yabanc1 sermaye yatırmlarını artırmak isteyen hükümetlerin vergi politikası girişimlerinin/teşviklerinin ekonomik maliyet-fayda ve sosyal maliyet-fayda analizi için periyodik bir inceleme yapması ve DYY girişleri için sağlanan teşviklerin ekonomik ve sosyal faydaları maliyetlerinden daha fazla ise bu teşvik politikalarını geliştirmeleri ve genişletmeleri gerekmektedir. Aksi halde maliyet fazla olduğunda sağalanan her bir teşvik devlet bütçesi için geniş anlamda bir kamu harcamasını ifade ettiğinden ve belirli bir oranda veya tuıtarda vergi gelirlerinden vazgeçilmesi anlamına geldiğinden bütçe dengesini de olumsuz etkileyebilecektir. 
Çalışmada yatırım yeri kararlarında yer alan birçok faktör arasından önemli bir gösterge olan vergi çekiciliği endeksi ve kontrol değişken olarak da ticari açıklık, ekonomik özgürlük endeksi ve kişi başına düşen milli gelirdeki artış oranı dikkate alınmıştır. Bundan sonraki yapılacak çalışmalarda DYY girişlerini etkileyebilecek siyasi istikrar, yerel pazarın büyüklügü, piyasalara yakınlık gibi faktörlerde analiz edilebilir. Ayrıca her bir teşvik kalemi farklı boyutta öneme sahip olduğu için vergi çekiciliği kalemlerinin her birinin ayrı ayrı incelenmesi ve buna göre DYY girişleri için hangi kalemlerde kolaylıklar sağlanması veya sağlanmaması gerektiği tahmin edilebilir.

\section{Kaynakça}

Alves, J. (2019). The impact of tax structure on investment: An empirical assessment for OECD countries. Public Sector Economics, 43(3), 291-309.

Babatunde, S.A. (2012). The Impact of tax incentives on foreign direct investment in the oil and gas sector in Nigeria. IOSR Journal of Business and Management, 6(1), 1-15.

Boly, A., Coulibaly, S. ve Kéré, E.N. (2019). Tax policy, foreign direct investment and spillover effects, Working Paper Series No: 310.

Cristina, P. O. (2012). Is taxation affecting the attractiveness of central and eastern europe countries for FDI?. Annals of the Constantin Brancusi University of Targu Jiu Economy Series, 1(1), $141-145$

Dinkel, A. (2015). Tax attractiveness and the allocation of risk within multinationals. Arqus Discussion Paper, No. 189.

Dinkel, A. ve Schanz, D. (2015). Tax attractiveness and the location of patents. Quantitative Research in Taxation-Discussion Papers, 188.

Dinkel, A., Keller, S. ve Schanz, D. (2014). Tax attractiveness and the location of german-controlled subsidiaries. Quantitative Research in Taxation-Discussion Papers, 142.

Driscoll, J.C., ve Kraay, A.C. (1998). Consistent covariance matrix estimation with spatially dependent panel data. Review of Economics and Statistics, 80(4), 549-560.

Hausman, J.A. (1978). Specification tests in econometrics, econometrica. Journal of The Econometric Society, 1251-1271.

Hsu, M., Lee, J., Leon-Gonzalez, R. ve Zhao, Y. (2019) Tax incentives and foreign direct investment in China, Applied Economics Letters, 26(9), 777-780.

Keller, S. ve Schanz D. (2013). Measuring tax attractiveness across countries. Arqus Discussion Paper, No. 143.

Lodhi, K. M. (2017). Tax incentives and impact on investment in Pakistan. Abasyn Journal of Social Sciences, 10 (1), 192-211.

Ngowi, H. (2000). Tax incentives for foreign direct investments (FDI): Types and who should/should not qualify in Tanzania?. The Tanzanet Journal, 1(1), 19-28.

OECD (2013). Addressing base erosion and profit shifting. OECD Publishing.

Pesaran, M. H. (2004). General diagnostic tests for cross section dependence in panels. University of Cambridge, Faculty of Economics, Cambridge Working Papers in Economics No. 0435.

Pesaran, M. H. (2007). A simple panel unit root test in the presence of cross-section dependence. Journal of Applied Econometrics, 22(2), 265-312. 
Schanz, D. Dinkel, A. ve Keller, S. (2017). Tax attractiveness and the location of German controlled subsidiaries. Review of Managerial Science, 11, 251-297.

Schanz, D., Keller, S., Dinkel, A., Fritz, J. ve Grosselfinger, C. (2020). The tax attractiveness index: Methodology, https://www.tax-index.org, (25.02.2020).

Simmons, R. S. (2000). Corporate taxation and the investment location decisions of multinational corporations. HKIBS Working Paper Series 035-990.

Simmons, R. S. (2003). An empirical study of the impact of corporate taxation on the global allocation of foreign direct investment: a broad tax attractiveness index approach. Journal of International Accounting, Auditing \& Taxation, 12, 105-120.

Ślusarczyk, B. (2018). Tax incentives as a main factor to attract foreign direct investments in Poland. Administratie si Management Public, (30), 67-81.

Şaşmaz, M. Ü. ve Bayar, Y. (2017). Mali teşvikler ile doğrudan yabancı sermaye girişleri arasındaki ilişkinin ARDL yaklaşımı ile analizi: Türkiye örneği. Yönetim Bilimleri Dergisi, 15(30), 297307.

Tahlova, S. ve Banociova, A. (2019). Assessment of corporate income tax revenues in the light of their current determinants. Montenegrin Journal of Economics, 15(1), 87-97.

Thuita, G.W. (2017). An investigation of the effect of tax incentives on the FDIs: A case of EPZs in Athi River Kenya. Journal of Accounting, Finance and Auditing Studies 3(1), 17-36.

Tung, S. ve Cho, S. (2000). The impact of tax incentives on foreign direct investment in China. Journal of International Accounting, Auditing \& Taxation, 9(2), 105-135.

Uras, Ö., Bektaş, H. ve Kayacan, E. (2019). Mali teşviklerin doğrudan yabancı sermaye girişleri üzerindeki etkisi. 235-248, türkiyede mali teşvik sistemi ve uygulamaları (ed. Taytak, mustafa ve şaşmaz mahmut Ünsal), ekin yayınevi.

Wooldridge, J.M. (2002). Econometric analysis of cross section and panel data. Cambridge, MA: MIT Press. 
Ek 1: Çalışmada Yer Alan Ülkeler

\begin{tabular}{|c|c|c|c|}
\hline \multicolumn{2}{|c|}{ Gelişmiş Ülkeler } & \multicolumn{2}{c|}{ Gelişmekte Olan Ülkeler } \\
\hline Almanya & Japonya & Angola & Lübnan \\
\hline ABD & Kanada & Arjantin & Makedonya \\
\hline Avustralya & Letonya & Banglades & Malezya \\
\hline Avusturya & Litvanya & Belarus & Meksika \\
\hline Bahama & Lüksemburg & Bolivya & Morityus \\
\hline Bahreyn & Macaristan & Botsvana & Namibya \\
\hline Belçika & Norveç & Brezilya & Nijerya \\
\hline İngiltere & Panama & Bulgaristan & Nikaragua \\
\hline Çek cumhuriyeti & Polonya & Cezayir & Pakistan \\
\hline Danimarka & Portekiz & Çin Halk Cumhuriyeti & Paraguay \\
\hline Estonya & Singapur & Dominik Cumhuriyeti & Peru \\
\hline Finlandiya & Slovakya & El Salvador & Romanya \\
\hline Fransa & Slovenya & Endonezya & Rusya \\
\hline Güney Kore & Suudi Arabistan & Fas & Sirbistan \\
\hline Hirvatistan & Şili & Filipinler & Tayland \\
\hline Hollanda & Uruguay & Guatemala & Tunus \\
\hline İrlanda & Yeni Zelanda & Güney Afrika & Türkiye \\
\hline İspanya & Yunanistan & Hindistan & Ukrayna \\
\hline İsrail & İtalya & Karadağ & Vietnam \\
\hline İsveç & İzlanda & Kazakistan & Kolombiya \\
\hline İsviçre & & Kenya & Kosta Rika \\
\hline
\end{tabular}


Vergi Çekiciliğinin Doğrudan Yabancı Yatırım Girişlerine Etkisi: Gelişmiş ve Gelişmekte....

Ek 2: Gelişmiş Ülkelerde Vergi Çekiciliği Endeksi ve Alt Bileşenleri Puanlaması (2018)

\begin{tabular}{|c|c|c|c|c|c|c|c|c|c|c|c|c|c|c|c|c|c|c|c|c|c|}
\hline $\begin{array}{l}\hat{E} \\
\text { 总 }\end{array}$ & 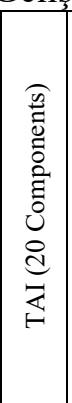 & 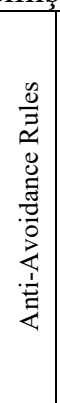 & 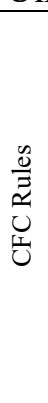 & 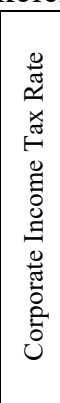 & 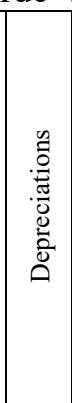 & 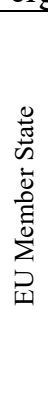 & 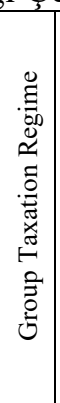 & 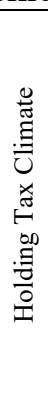 & 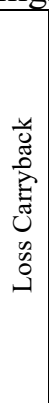 & 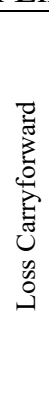 & 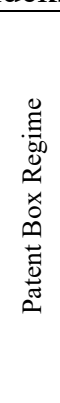 & 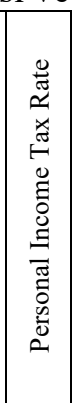 & 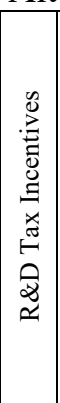 & 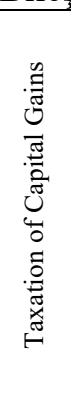 & 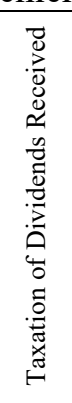 & 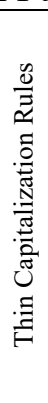 & 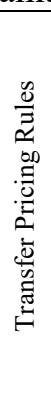 & 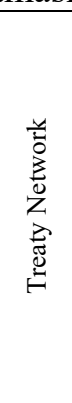 & 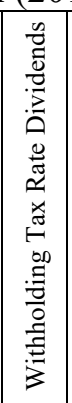 & 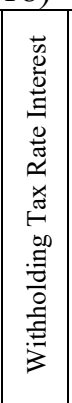 & 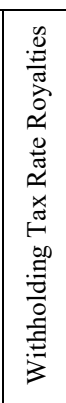 \\
\hline Bahrain & 0,92 & 1 & 1 & 1 & 1 & 0 & 1 & 1 & 1 & 1 & 1 & 1 & 1 & 1 & 1 & 1 & 1 & 0,34 & 1 & 1 & 1 \\
\hline Bahamas & 0,9 & 1 & 1 & 1 & 1 & 0 & 1 & 1 & 1 & 1 & 1 & 1 & 1 & 1 & 1 & 1 & 1 & 0 & 1 & 1 & 1 \\
\hline Singapore & 0,66 & 0 & 1 & 0,56 & 0 & 0 & 0,5 & 1 & 1 & 1 & 0,56 & 0,63 & 1 & 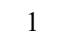 & 1 & 1 & 0 & 0,67 & 1 & 0,57 & 0,71 \\
\hline Netherlands & 0,61 & 0 & 1 & 0,36 & 0,68 & 1 & 0,5 & 0 & 1 & 0,5 & 0,82 & 0,11 & 1 & 1 & 1 & 0 & 0 & 0,75 & 0,57 & 1 & 1 \\
\hline Latvia & 0,6 & 0,5 & 1 & 0,36 & 1 & 1 & 0 & 0 & 1 & 1 & 0,36 & 0,28 & 0 & 1 & 1 & 0 & 0 & 0,48 & 1 & 1 & 1 \\
\hline Estonia & 0,59 & 0 & 0 & 0,49 & 1 & 1 & 0 & 0 & 1 & 1 & 0,49 & 0,66 & 0 & 1 & 1 & 1 & 0 & 0,45 & 1 & 1 & 0,71 \\
\hline Luxembourg & 0,59 & 0,5 & 1 & 0,33 & 0,61 & 1 & 0,5 & 0 & 0 & 0,5 & 0,87 & 0,22 & 0,5 & 1 & 1 & 0,5 & 0 & 0,63 & 0,57 & 1 & 1 \\
\hline Ireland & 0,54 & 0 & 1 & 0,68 & 0,83 & 1 & 0,5 & 0 & 1 & 1 & 0,84 & 0,18 & 0,5 & 1 & 0 & 0 , & 0 & 0,58 & 0,43 & 0,43 & 0,41 \\
\hline Austria & 0,54 & 0 & 1 & 0,36 & 0,74 & 1 & 1 & 0 & 0 & 1 & 0,36 & 0,06 & 0,5 & 1 & 1 & 0,5 & 0 & 0,71 & 0,21 & 1 & 0,41 \\
\hline United Kingdom & 0,54 & 0 & 0 & 0,51 & 0 & 1 & 0,5 & 0 & 1 & 1 & 0,74 & 0,23 & 1 & 1 & 1 & 0 & 0 & 1 & 1 & 0,43 & 0,41 \\
\hline Hunga & 0,53 & 0,5 & 0 & 0,77 & 0,68 & 1 & 0 & 0 & 0 & 0 & 0,88 & 0,74 & 0,5 & 1 & 1 & 0 & 0 &, 63 & 1 & 1 & 1 \\
\hline Lithuania & 0,53 & 0 & 0 & 0,62 & 0,97 & 1 & 0 & 0 & 0 & 1 & 0,87 & 0,74 & 1 & 1 & 1 & 0 & 0 & 0,43 & 0,57 & 0,71 & 0,71 \\
\hline Sweden & 0,53 & 0 & 0 & 0,44 & 0,87 & 1 & 0,5 & 0 & 0 & 1 & 0,44 & 0,03 & 0,5 & 1 & 1 & 1 & 0 & 0,67 & 0,14 & 1 & 1 \\
\hline Spain & 0,52 & 0 & 0 & 0,36 & 0,68 & 1 & 0,5 & 1 & 0 & 1 & 0,74 & 0,23 & 1 & 1 & 1 & 0 & 0 & 0,74 & 0,46 & 0,46 & 0,29 \\
\hline Czech Republic & 0,49 & 0,5 & 1 & 0,51 & 0,68 & 1 & 0 & 0 & 0 & 0 & 0,51 & 0,63 & 0 & 1 & 1 & 0 & 0 &, 7 & 0,57 & 0,57 & 0,56 \\
\hline France & 0,48 & 0 & 0 & 0,12 & 0,87 & 1 & 0,5 & 0 & 1 & 1 & 0,62 & 0 & 0,5 & 0,88 & 0,9 & 0 & 0 & 0,98 & 0,14 & 1 & 0,02 \\
\hline Slovenia & 0,48 & 0,5 & 1 & 0,51 & 0,77 & 1 & 0 & 0 & 0 & 1 & 0,51 & 0,15 & 0,5 & 0,5 & 0,95 & 0 & 0 & 0,46 & 0,57 & 0,57 & 0,56 \\
\hline Italy & 0,47 & 0 & 0 & 0,28 & 0,77 & 1 & 1 & 0 & 0 & 1 & 0,64 & 0,21 & 1 & 0,95 & 0,95 & 0 & 0 & 0,8 & 0,26 & 0,26 & 0,34 \\
\hline Germany & 0,47 & 0 & 0 & 0,24 & 0,77 & 1 & 0 , & 0 & 1 & 1 & 0,24 & 0,19 & 0 & 0,95 & 0,9 & 0 & 0 & 0,76 & 0,25 & 1 & 0,53 \\
\hline Switze & 0 & 0 & 1 & 0,46 & 0 & 1 & 0 & 1 & 0 & 0,5 & 0,46 & 32 & 0 & 1 & 1 & 0 & 0 & 84 & 0 & 0 & 1 \\
\hline Norway & 0,46 & 0,5 & 0 & 0,41 & 0,55 & 0 & 0,5 & 0 & 0 & 1 & 0,41 & 0,35 & 0,5 & 1 & 1 & 0 & 0 & 0,69 & 0,29 & 1 & 1 \\
\hline Croatia & 0,45 & 0,5 & 1 & 0,54 & 0,87 & 1 & 0 & 0 & 0 & 0 & 0,54 & 0,28 & 1 & 0 & 1 & 0 & 0 & 0,49 & 0,66 & 0,57 & 0,56 \\
\hline Belgit & 0,43 & 0 & 1 & 0,24 & 0,77 & 1 & 0 & 0 & 0 & 1 & 0,89 & 0,09 & 0 , & 1 & 1 & 0 & 0 & 0,75 & 0,14 & 0,14 & 0,12 \\
\hline Saudi & 42 & 0 & 1 & 0,49 & 0,77 & 0 & 0 & 0 & 0 & 1 & 0 & 1 & 0 & 0 & 0 & 0 & 1 & 0,35 & 0,86 & 0,86 & 0,56 \\
\hline Denm & 0,42 & 0 & 0 & 0,44 & 0,83 & 1 & 0,5 & 0 & 0 & 1 & 0,44 & 0,11 & 0 & 1 & 1 & 0 & 0 & 6 & 0,23 & 0,37 & 0,35 \\
\hline Slovak Republic & 0,42 & 0 & 1 & 0,46 & 0,87 & 1 & 0 & 0 & 0 & 0 & 0,46 & 0,57 & 0,5 & 1 & 1 & 0 & 0 & 0,54 & 0 & 0,46 & 0,44 \\
\hline Finland & 0,41 & 0 & 0 & 0,49 & 0,72 & 1 & 0,5 & 0 & 0 & 0,5 & 0,49 & 0,16 & 0 & 1 & 1 & 0 & 0 & 0,6 & 0,43 & 1 & 0,41 \\
\hline Panama & 0,41 & 1 & 1 & 0,36 & 0,8 & 0 & 0 & 0 & 0 & 0 & 0,36 & 0,57 & 0 & 0 & 1 & 1 & 0 & 0,13 & 0,71 & 0,64 & 0,63 \\
\hline lanc & 0,39 & 0,5 & 0 & 0,49 & 0,77 & 0 & 0,5 & 0 & 0 & 0,5 & 0,49 & ,21 & 0,5 & 1 & 1 & 0 & 0 & 0,35 & 0,43 & 0,66 & 0,41 \\
\hline Australia & 0,36 & 0 & 0 & 0,23 & 0,74 & 0 & 0,5 & 0 & 0 & 1 & 0,23 & 0,2 & 1 & 1 & 1 & 0 & 0 & 0,36 & 0,14 & 0,71 & 0,12 \\
\hline Poland & 0,35 & 0 & 0 & 0,51 & 0,61 & 1 & 0,5 & 0 & 0 & 0 & 0,51 & 0,45 & 0,5 & 0 & 1 & 0 & 0 & 0,65 & 0,46 & 0,43 & 0,41 \\
\hline
\end{tabular}




\begin{tabular}{|c|c|c|c|c|c|c|c|c|c|c|c|c|c|c|c|c|c|c|c|c|c|}
\hline Portugal & 0,35 & 0 & 0 & 0,19 & 0,68 & 1 & 0,5 & 0 & 0 & 0 & 0,6 & 0,1 & 0,5 & 1 & 1 & 0 & 0 & 0,6 & 0,29 & 0,29 & 0,26 \\
\hline New Zealand & 0,34 & 0 & 0 & 0,28 & 0,65 & 0 & 0,5 & 0 & 0 & 1 & 0,28 & 0,44 & 0 & 1 & 1 & 0 & 0 & 0,32 & 0,14 & 0,57 & 0,56 \\
\hline Uruguay & 0,33 & 0,5 & 0 & 0,36 & 0,68 & 0 & 0 & 0 & 0 & 0 & 0,36 & 0,39 & 0 & 0 & 1 & 1 & 0 & 0,15 & 0,8 & 0,66 & 0,65 \\
\hline Japan & 0,32 & 0 & 0 & 0,21 & 0,68 & 0 & 0,5 & 0 & 1 & 0,5 & 0,21 & 0,05 & 0,5 & 0 & 0,95 & 0 & 0 & 0,54 & 0,42 & 0,42 & 0,4 \\
\hline Canada & 0,31 & 0 & 0 & 0,32 & 0,72 & 0 & 0 & 0 & 1 & 0,5 & 0,32 & 0,09 & 0,5 & 0,5 & 0 & 0 & 0 & 0,73 & 0,29 & 1 & 0,26 \\
\hline Greece & 0,3 & 0 & 0 & 0,26 & 0,83 & 1 & 0 & 0 & 0 & 0 & 0,26 & 0,06 & 0,5 & 0 & 1 & 0 & 0 & 0,44 & 0,57 & 0,57 & 0,41 \\
\hline United States & 0,28 & 0 & 0 & 0,33 & 0,74 & 0 & 0,5 & 0 & 0 & 1 & 0,33 & 0,22 & 0,5 & 0 & 1 & 0 & 0 & 0,52 & 0,14 & 0,14 & 0,12 \\
\hline Israel & 0,28 & 0 & 0 & 0,41 & 0,61 & 0 & 0 & 1 & 0 & 1 & 0,41 & 0,2 & 0 & 0 & 0 & 0,5 & 0 & 0,43 & 0,29 & 0,34 & 0,32 \\
\hline Korea & 0,25 & 0 & 0 & 0,29 & 0,74 & 0 & 0,5 & 0 & 0 & 0,5 & 0,47 & 0,21 & 0,5 & 0 & 0 & 0 & 0 & 0,75 & 0,37 & 0,37 & 0,35 \\
\hline Chile & 0,17 & 0 & 0 & 0,31 & 0,55 & 0 & 0 & 0 & 0 & 1 & 0,31 & 0,4 & 0,5 & 0 & 0 & 0 & 0 & 0,25 & 0 & 0 & 0,12 \\
\hline
\end{tabular}

Ek 3: Gelişmekte Olan Ülkelerde Vergi Çekiciliği Endeksi ve Alt Bileșenleri Puanlaması (2018)

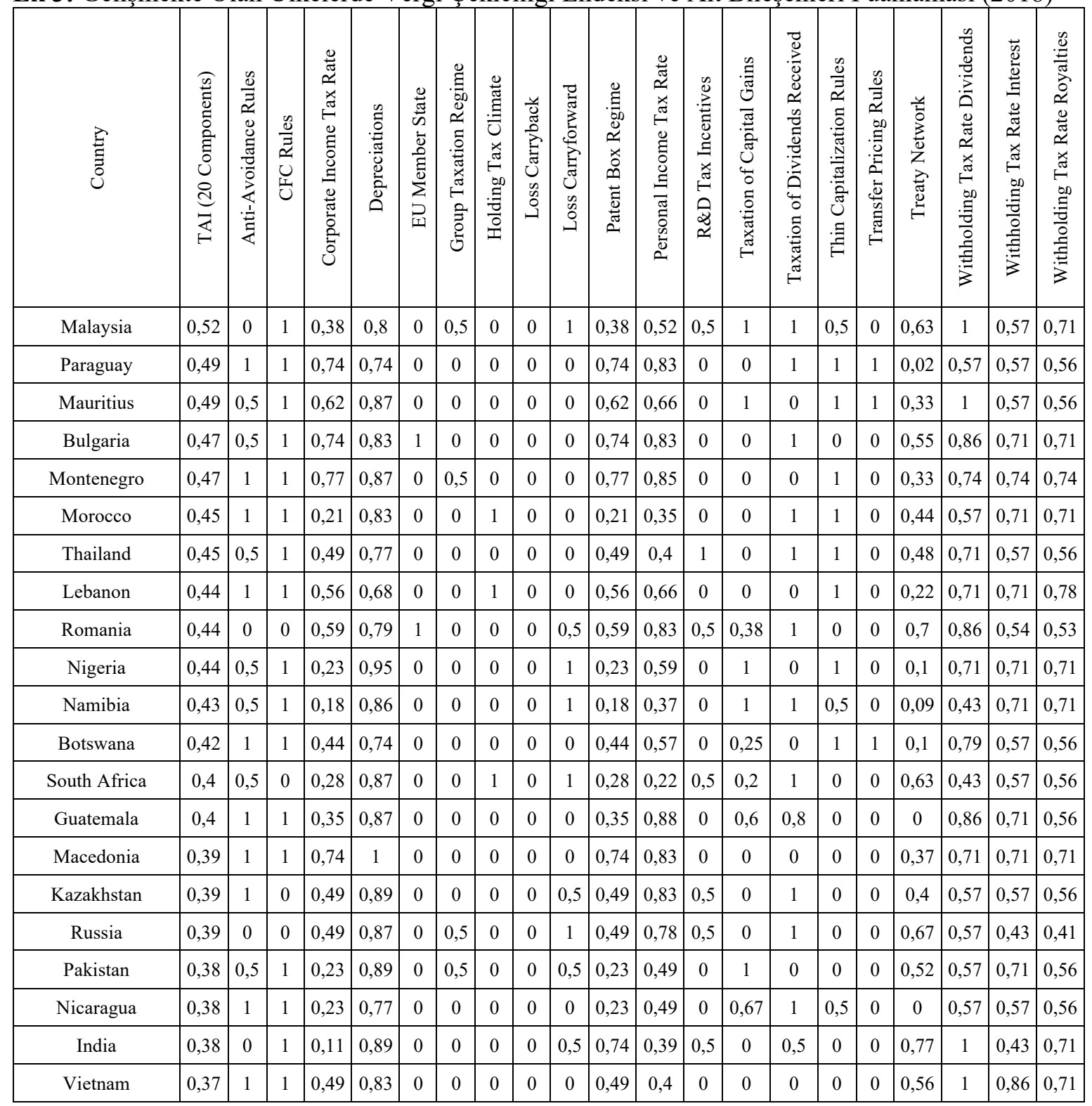


Vergi Çekiciliğinin Doğrudan Yabancı Yatırım Girişlerine Etkisi: Gelişmiş ve Gelişmekte....

\begin{tabular}{|c|c|c|c|c|c|c|c|c|c|c|c|c|c|c|c|c|c|c|c|c|c|}
\hline Costa Rica & 36 & 1 & 1 & 0,23 & 0,68 & 0 & 0 & 0 & 0 & 0 & 0,23 & 0,74 & 0 & 1 & 1 & 0 & 0 & 02 & 0,57 & 0,57 & 0,26 \\
\hline Kenya & 0,36 & 0 & 1 & 0,23 & 1 & 0 & 0 & 0 & 0 & 0,5 & 0,23 & 0,49 & 0 & 1 & 1 & 0 & 0 & 0,1 & 0,71 & 0,57 & 0,41 \\
\hline Bolivia & 0,36 & 1 & 1 & 0,36 & 0,74 & 0 & 0 & 0 & 0 & 0 & 0,36 & 0,78 & 0 & 0 & 1 & 0 & 0 & 0,07 & 0,64 & 0,64 & 0,63 \\
\hline Tunisi & 6 & 0,5 & 1 & 6 & 37 & 0 & 0,5 & 0 & 0 & 0 & 0,36 & 9 & 0 & 0 & 1 & 0 & 0 & 43 & 0,71 & 43 & 0,56 \\
\hline Angola & 0,35 & 0,5 & 1 & 0,23 & 0,83 & 0 & 0,5 & 0 & 0 & 0 & 0,23 & 0,71 & 0 & 0 & 1 & 0 & 0 & 0 & 0,71 & 0,57 & 0,71 \\
\hline Turkey & 0,35 & 0 & 0 & 0,44 & 0,55 & 0 & 0 & 0 & 0 & 0 & 0,72 & 0,4 & 0,5 & 1 & 1 & 0 & 0 & 0,66 & 0,57 & 0,71 & 0,41 \\
\hline Ukrai & 34 & 0 & 1 & 54 & 0,77 & 0 & 0 & 0 & 0 & 1 & 0,54 & 0,67 & 0 & 0 & 0 & 0 & 0 & 58 & 0,57 & 0,57 & 0,56 \\
\hline Belarus & 0,33 & 0 & 1 & 0,54 & 0,48 & 0 & 0 & 0 & 0 & 0,5 & 0,54 & 0,78 & 0 & 0 & 0,33 & 0 & 0 & 0,54 & 0,66 & 0,71 & 0,56 \\
\hline Bangl & 33 & 0 & 1 & 0,1 & 0,89 & 0 & 0 & 0 & 0 & 0,5 & 0,1 & 0,49 & 0 & 0,57 & 0,43 & 1 & 0 & 0,24 & 0,43 & 0,43 & 0,41 \\
\hline Algeria & 0,31 & 0,5 & 1 & 0,33 & 0,77 & 0 & 0,5 & 0 & 0 & 0 & 0,33 & 0 & 0 & 0 & 0 & 0,5 & 0 & 0,28 & 0,57 & 0,71 & 0,29 \\
\hline Serbia & 0,3 & 0 & 1 & 0,62 & 0,74 & 0 & 0,5 & 0 & 0 & 0 & 0,62 & 0,74 & 0 & 0 & 0 & 0 & 0 & 0,46 & 0,43 & 0,43 & 0,41 \\
\hline Dominican $\mathrm{P}$ & 0,28 & 0 & 1 & 0,31 & 0,77 & 0 & 0 & 0 & 0 & 0 & 0,31 & 0,57 & 0 & 0 & 1 & 0 & 0 & 02 & 0,71 & 0,71 & 0,2 \\
\hline El Salvador & 0,28 & 0 & 1 & 0,23 & 0,87 & 0 & 0 & 0 & 0 & 0 & 0,23 & 0,49 & 0 & 0 & 1 & 0 & 0 & 0,01 & 0,86 & 0,43 & 0,41 \\
\hline Brazil & 0,28 & 0 & 0 & 0,13 & 0,83 & 0 & 0 & 0 & 0 & 1 & 0,13 & 0,53 & 0,5 & 0 & 0 & 0 & 0 & 0,25 & 1 & 0,57 & 0,56 \\
\hline Philip & 0 , & 0,5 & 1 & 0,23 & 1 & 0 & 0 & 0 & 0 & 0 & 3 & 0 , & 0 & 0 & 0 & 0 , & 0 & 0,33 & 0,14 & 0,43 & 12 \\
\hline Mexico & 0,27 & 0 & 0 & 0,23 & 0,87 & 0 & 0,5 & 0 & 0 & 0,5 & 0,23 & 0,4 & 0,5 & 0 & 0 & 0 & 0 & 0,44 & 0,71 & 0,71 & 0,26 \\
\hline Colombia & 0,27 & 0 & 0 & 0,05 & 0,71 & 0 & 0 & 0 & 0 & 0,5 & 0,05 & 0,44 & 0,5 & 0 & 1 & 0 & 0 & 0,1 & 0,86 & 0,57 & 0,56 \\
\hline bi & 0,26 & 0 & 0 & 36 & 0,87 & 0 & 0 & 0 & 0 & 0 & 0,36 & 0,23 & 0,5 & 0 & 0 & 0 & 0 & 0,8 & 0,71 & 0,71 & 0,71 \\
\hline Indonesia & 0,24 & 1 & 0 & 0,36 & 0,87 & 0 & 0 & 0 & 0 & 0 & 0,36 & 0,49 & 0 & 0 & 0 & 0 & 0 & 0,52 & 0,43 & 0,43 & 0,41 \\
\hline Peru & 0,23 & 0 & 0 & 0,24 & 0,87 & 0 & 0 & 0 & 0 & 1 & 0,24 & 0,49 & 0,5 & 0 & 0 & 0 & 0 & 0,08 & 0,86 & 0,14 & 0,12 \\
\hline Argentina & 0,15 & 0 & 0 & 0,23 & 0,68 & 0 & 0 & 0 & 0 & 0 & 0,23 & 0,4 & 0,5 & 0 & 0 & 0 & 0 & 0,15 & 0,8 & 0 & 0,07 \\
\hline
\end{tabular}

